\title{
The impact of major warming at 14.7 ka on environmental changes and activity of Final Palaeolithic hunters at a local scale (Orawa-Nowy Targ Basin, Western Carpathians, Poland
}

\author{
Anna Lemanik $^{1}$ (D) $\cdot$ Mateusz Baca ${ }^{2}$ (D) $\cdot$ Krzysztof Wertz $^{1}$ (D) $\cdot$ Paweł Socha $^{3}$ (D) $\cdot$ Danijela Popović $^{2,4}$ (D) \\ Teresa Tomek $^{1}$ (D) - Grzegorz Lipecki ${ }^{1}$ (D) - Anna Kraszewska ${ }^{5}$ (D) - Barbara Miękina ${ }^{1}$ (D) - Aleksandra Żeromska ${ }^{6}$ (D) \\ Andrea Pereswiet-Soltan ${ }^{3}$ (D) Zbigniew Szyndlar $^{1}$ (D) $\cdot$ Magda Cieśla $^{5}$ (I) $\cdot$ Paweł Valde-Nowak $^{7}$ (D) \\ Paweł Mackiewicz ${ }^{6}$ (D) Adam Nadachowski ${ }^{1}$ (D)
}

Received: 18 September 2019 / Accepted: 15 January 2020 / Published online: 6 February 2020

(C) The Author(s) 2020

\begin{abstract}
There is a widespread belief that the abrupt warming at $14.7 \mathrm{ka}$ had a profound impact on the environment. However, the direct correlation between the global climatic event and changes in local environments is not obvious. We examined faunal succession in an intra-mountain basin of the Western Carpathians to assess the potential influence of the climatic change between Greenland Stadial-2a and Greenland Interstadial-1e on the local environment. We investigated three vertebrate assemblages (total number of identified specimens $=18,745$; minimum number of individuals $=7515 ; 138$ taxa) from Obłazowa Cave (western entrance) and a Rock overhang in Cisowa Rock, radiocarbon dated to the period before and after the global warming, between ca. 17.0 and $14.0 \mathrm{ka}$. Our data revealed that the major abrupt warming that occurred $14.7 \mathrm{ka}$ had little impact on the local environment, which could suggest that ecosystems in Central Europe were resilient to the abrupt global climate changes. The increase in fauna population sizes and species diversities in local biotopes was gradual and began long before the temperature increase. This was supported by the analysis of ancient DNA of Microtus arvalis, which showed a gradual increase in effective population size after $19.0 \mathrm{ka}$. The results of palaeoclimatic reconstruction pointed out that the compared sites were characterized by similar climatic conditions. According to our calculations, the differences in the annual mean temperatures did not exceed $0.5^{\circ} \mathrm{C}$ and mean
\end{abstract}

This article is part of the Topical Collection on Post-glacial human subsistence and settlement patterns

Anna Lemanik and Mateusz Baca contributed equally and should be regarded as joint first authors.

Paweł Mackiewicz and Adam Nadachowski should be regarded joint senior authors.

Electronic supplementary material The online version of this article (https://doi.org/10.1007/s12520-020-01020-6) contains supplementary material, which is available to authorized users.

Mateusz Baca

bacamat@gmail.com

$\bowtie$ Adam Nadachowski nadachowski@isez.pan.krakow.pl

1 Institute of Systematics and Evolution of Animals, Polish Academy of Sciences, Sławkowska 17, 31-016 Kraków, Poland

2 Laboratory of Palaeogenetics and Conservation Genetics, Centre of New Technologies, University of Warsaw, S. Banacha 2c, 02-079 Warszawa, Poland

3 Department of Palaeozoology, Institute of Environmental Biology, Wrocław University, Sienkiewicza 21, 50-335 Wrocław, Poland
4 Institute of Biochemistry and Biophysics, Polish Academy of Sciences, Pawińskiego 5a, 02-106 Warszawa, Poland

5 Institute of Archaeology, Jagiellonian University, Gołębia 11, 31-007 Kraków, Poland

6 Department of Bioinformatics and Genomics, Faculty of Biotechnology, Wrocław University, Joliot-Curie 14a, 50-383 Wrocław, Poland

7 University of Hradec Králové, Faculty of Arts, Department of Archeology, Rokitanského 62, 50003 Hradec Králové, Czech Republic 
annual thermal amplitude changed from 22.9 to $22.4{ }^{\circ} \mathrm{C}$. The environmental changes before $14.7 \mathrm{ka}$ had no impact on the activity of Final Palaeolithic hunters in the studied area.

Keywords Palaeoenvironmental reconstruction $\cdot$ Faunal succession $\cdot$ Obłazowa Cave $\cdot$ Magdalenian $\cdot$ Global warming $\cdot$ Climate change

\section{Introduction}

Environmental conditions are frequently considered a key component of the mode of life of Palaeolithic people, including both Neanderthals and anatomically modern humans. As a result, understanding changes in environments occupied by humans has become a main objective of prehistoric research. This knowledge is essential for reconstructing the subsistence strategies and abilities that allowed hunter-gatherers to adapt to changing environments. Pleistocene climate oscillations are thought to have greatly affected plant and animal communities re-organizing biotopes and whole ecosystems (Jackson and Blois 2015; Maguire et al. 2015); these environmental changes, in turn, also impacted past human societies.

Over the last years, studies have shown that the climate structure and changes that occurred between cold Greenland Stadials (GS) and warm Greenland Interstadials (GI), as documented in Greenland ice cores, particularly those from the last glacial period, had great millennial variabilities and reproducible patterns at the global scale (Wolff et al. 2010). In the Northern Hemisphere, in every cycle, the onset of warming events was very rapid and occurred in only a few decades, and mean annual temperature changes were even as high as between 8 and $15^{\circ} \mathrm{C}$ (Huber et al. 2006).

The whole period of successive warming, sometimes called the post-LGM (post-Last Glacial Maximum), lasted about 6.3 $\mathrm{ka}$, from around $18.0 \mathrm{ka}$ to the beginning of the Holocene at $11.7 \mathrm{ka}$, and was characterized by two major rapid warming phases during the deglaciation period, and has been documented in both marine and terrestrial ecosystems (e.g. Allen et al. 1999; Fletcher et al. 2010; Moreno et al. 2014; Rasmussen et al. 2014). The shifts between the cold and mild periods were, as in previous climatic pulses, also very fast, as exemplified by the climatic change ca. $14.7 \mathrm{ka}$ between the end of the Pleniglacial (Greenland Stadial-2a, i.e. GS-2a, an equivalent of the Oldest Dryas) and the beginning of the Late Glacial (Greenland Interstadial-1e, GI-1e, an equivalent of Bølling interstadial), when temperatures increased rapidly by $3-5{ }^{\circ} \mathrm{C}$ across western Europe (Renssen and Isarin 2001). The duration of the GS-2/GI-1 climatic change in Greenland lasted only less than a decade (Steffensen et al. 2008). This climatic shift is considered to be accompanied also by global environmental changes (Blockley et al. 2012; Clark et al. 2012; Shakun et al. 2012; Feurdean et al. 2014, among others).
It is therefore interesting to assess the influence of the rapid and large increase in temperatures, as well as of the humidity regime in the Northern Atlantic region and Greenland on particular plant and animal communities, e.g. in Central Europe. However, the impact of these global climatic changes, detected in the Greenland ice cores, on local environments as well as the correlation between discontinuous archaeological events and these geographically distant, only indirectly connected climatic regions are not inevitably applicable. The potential influence of the global climate on a given environment can be altered by the specific conditions and diversities of local landscapes and biotopes. Therefore, to understand humanenvironment interactions and vulnerability of local ecosystems to climate changes, it is essential to carry out detailed analyses of local palaeoenvironmental conditions in the context of global climate shifts.

To check the potential impact of global climate change on a local environment around the GS-2/GI-1 transition, we investigated succession in very rich faunal communities (amphibians, reptiles, birds and mammals) documented at two sites in north Central Europe: Obłazowa Cave (western entrance) and a Rock overhang in Cisowa Rock, both of which are in the same intra-mountain basin, the Orawa-Nowy Targ Basin, Western Carpathians, Poland. The sites include valuable deposits that accumulated continuously from ca. 17.0 to $14.0 \mathrm{ka}$. Palaeontological studies of vertebrates for archaeological and palaeoenvironmental purposes usually classify fauna into two categories, based on the size of preserved organism remains: (I) the megafauna, including large mammals, important for evaluating human subsistence strategies and patterns, and (II) the so-called small vertebrates, containing amphibians, reptiles, small bird species, insectivores, bats, rodents and lagomorphs, which can be used to reconstruct the palaeoenvironment. Small mammals, particularly rodents, have specific environmental and climatic requirements, especially relating to temperature and moisture gradients, available plant types and soil types in the areas they dig their burrows. Because of their high reproductive rates, small mammals can respond quickly to environmental changes, and this combined with their restricted territories and short migration distances, makes the group a very good indicator of the environment at local and/or regional scales (e.g. Hernández Fernández 2006; López-García et al. 2010; Socha 2014; Royer et al. 2016; Berto et al. 2017, among many others). Knowledge of small vertebrate assemblages at given time points makes it possible 
to reconstruct past environments even during short climatic oscillations. Moreover, an additional advantage of small mammal assemblages is their abundance and richness, which enables the application of multiple statistical approaches and quantitative methods. To understand the population dynamics of small mammals around the GS-2/GI-1 transition, we additionally carried out genetic analysis of the common vole (Microtus arvalis), one of the predominant species in the assemblages, to reconstruct changes in its effective population size. Analyses of ancient DNA provide an independent information on population dynamics.

Fossil avian assemblages also supply useful environmental data at local scales; however, birds have high daily and seasonal migration abilities that must be taken into account. In the case of migrant species, the only reliable proof of their longterm presence in a given area is finding evidence of nesting and reproduction. Thus, palaeoenvironmental reconstructions based on bird fossils are particularly useful when remains of either sedentary species or young individuals of migratory birds are present in the faunal assemblages.

Amphibians and reptiles are commonly considered good indicators of past climates, although in higher latitudes there occur species adapted to the cold climate, and having wide ranges of occurrence. That is why they were not used in palaeoecological research in this work.

We also examined the link between the community structures of small mammals and birds, reflecting environmental changes at the local scale, with the activity of Final Palaeolithic hunters that inhabited the Western Carpathians.

\section{Studied area}

Remnants of Palaeolithic settlements in the Polish Western Carpathians are scarce, with the exception of the Podhale region, a southern part of the Orawa-Nowy Targ Basin (ValdeNowak 1991). The basin has a complex tectonic history and is ca. $65 \mathrm{~km}$ long and up to 15-20 km wide, covering an area of ca. $300 \mathrm{~km}^{2}$. It was formed during the Miocene and is partly filled with Neogene lacustrine deposits covered by large Pleistocene fluvioglacial fans of gravels, up to ca. $100 \mathrm{~m}$ thick (Tokarski et al. 2012). The basin is an intra-montane depression, surrounded from the west, north and east by the Flysch Carpathians and from south by the Tatra Mountains (Eanczont et al. 2019).

In the Podhale region, three neighbouring sites, Nowa Biała, site 1, Obłazowa Cave (also known as Nowa Biała, site 2) and the Rock overhang in Cisowa Rock, have been discovered in recent decades, all located in or close to the gorge of the Białka River, a tributary of the Dunajec River (ValdeNowak 1987; Valde-Nowak et al. 2003; Nadachowski and Valde-Nowak 2015; Valde-Nowak et al. 2018; Łanczont et al. 2019) (Fig. 1). The sites are in the lower part of
Podhale, at elevations of ca. 650-700 m a.s.l., in the Pieniny Klippen Belt zone, with characteristic rocky hills that emerge in some places over a flat landscape. There are river terrace deposits in the neighbourhood of Obłazowa and Cisowa Rocks originating from the last glacial (Vistulian, Weichselian) (Baumgart-Kotarba 1996). The most important sites in this study became the multi-layered Palaeolithic Obłazowa Cave and Rock overhang in Cisowa Rock. Both sites are rich in vertebrate remains and are only $1900 \mathrm{~m}$ away from each other (Fig. 2). Nowa Biała 1 site did not contain animal remains (Lanczont et al. 2019).

\section{Excavation sites}

\section{The Rock overhang in Cisowa Rock (RCR)}

The Rock overhang in Cisowa Rock (49 $26^{\prime} 10^{\prime \prime} \mathrm{N}, 20^{\circ} 06^{\prime}$ $13^{\prime \prime} \mathrm{E}$ ) is near Gronków, at the base of the rock (685 $\mathrm{m}$ a.s.1.) and is completely filled with sediments (Fig. 3a). The cavity was discovered in 2009 and a regular excavation campaign was undertaken in 2013 . A trench $(5 \times 5 \times 0.6 \mathrm{~m})$ was dug near the rocky wall and the whole sediment was wet sieved to discover any small teeth and bones. Preliminary studies of the faunal assemblages from layers III and I/II, yielded abundant fossil fauna with a predominance of rodents characteristic of steppe-tundra environments of the last glacial (Nadachowski and Valde-Nowak 2015); their age was confirmed by radiocarbon dating provided in this paper. The fossil remains used for this study included the whole material collected in 2013.

\section{The Obłazowa Cave, western entrance [OB(WE)]}

The Obłazowa Cave is located near Nowa Biała $\left(49^{\circ} 25^{\prime} 48^{\prime \prime}\right.$ $\mathrm{N}, 20^{\circ} 09^{\prime} 36^{\prime \prime} \mathrm{E}$ ), on the orographic left bank of the Białka River (Fig. 3b). The cave is in the southern part of Obłazowa Rock (688 m a.s.l.), which belongs to the Pieniny Klippen Belt, which consists of many separate rocks (klippe) that form characteristic elements of the landscape. The site is first of all known from the spectacular discovery of a boomerang made from a mammoth tusk (Valde-Nowak et al. 1987; ValdeNowak 1991) as well as the oldest anatomically modern human (Homo sapiens) remains found in Poland (Gleń-Haduch 2003; Trinkaus et al. 2014). Obłazowa Cave yielded a number of important Mousterian, Szeletian, Aurignatian, Micoquian, Pavlovian and Magdalenian archaeological assemblages (Valde-Nowak et al. 2003; Valde-Nowak and Nadachowski 2014; Valde-Nowak et al. 2018) as well as a diversified fauna of molluscs, amphibians, reptiles, birds and both small and large mammals of the Late Pleistocene age, all discovered in a series of sediments divided into 21 layers (Valde-Nowak et al. 2003). 
Fig. 1 View from Obłazowa Rock to the gorge and valley of the Białka River, in Podhale region, Western Carpathians, Poland. Photo. Piotr Jamiński

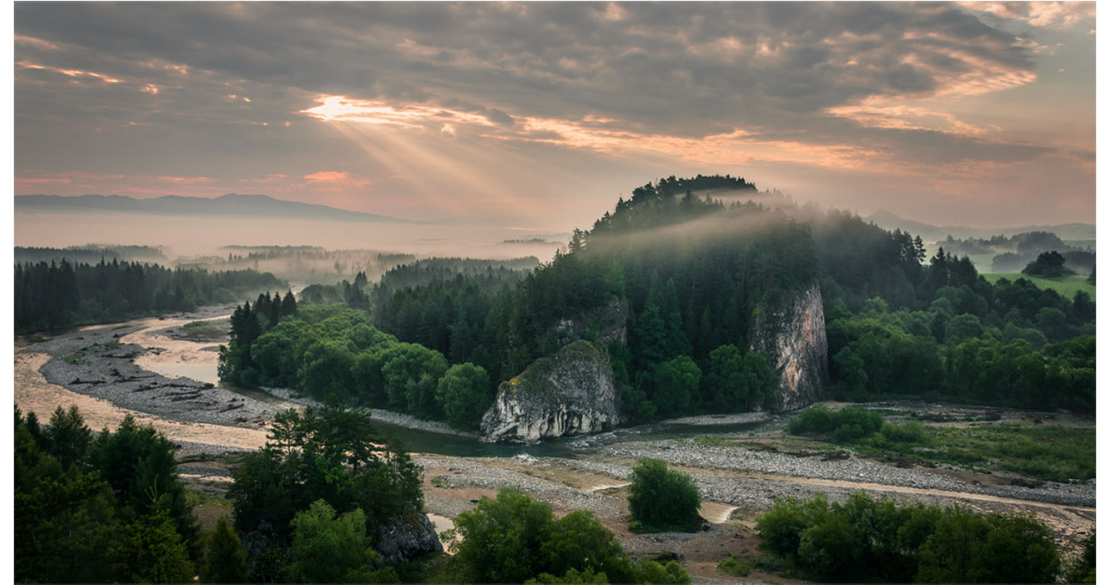

In 2009, a small trench was set up in the front of the western entrance to Obłazowa Cave [OB(WE), Fig. 3c]. Nadachowski and Valde-Nowak (2015) described part of the animal remains recovered during the field exploration in 2009. Direct dates obtained from bones of wild horse and reindeer place the faunal assemblage between the younger part of the GS-2 (Oldest Dryas) and the beginning of GS-1e (Bølling). The exploration of this part of Obłazowa Cave was continued over the next years, especially in 2015 and 2016, leading to the discovery of the Late Magdalenian artefacts and a fireplace in layer II, dated to GI-1d/GI-1c 3 , the boundary between Bølling and Allerød (Valde-Nowak et al. 2018). The excavation yielded numerous remains of small mammals and birds together with less abundant bones of amphibians, reptiles and large mammals. Stratigraphic correlation of sediments from layers III and II in $\mathrm{OB}(\mathrm{WE})$ to the respective layers in the main chamber of Obłazowa Cave (Valde-Nowak et al. 2003) is not clear and requires further study.

\section{Material and methods}

\section{Fossil assemblages, taxonomic diversity and taphonomy}

The whole fossil assemblage excavated in 2013 from the RCR site was studied and comprised in total 3692 identified bones and teeth, which correspond to a minimum of 2006 individuals, representing at least 53 taxa, including amphibians, reptiles, birds and various species of mammals with a distinct predominance of small-sized species (Table 1, Fig. 4, Supplementary Tables S1, S2 and S3). For the OB(WE) site, the analysed material was restricted to remains collected from an area of $4 \mathrm{~m}^{2}(\mathrm{~N} 4, \mathrm{~N} 3, \mathrm{M} 4$ and M3) around the Magdalenian fireplace (Valde-Nowak et al. 2018), and this was enough to find potential differences in the faunal compositions of layers III and II. The faunal assemblage in $\mathrm{OB}(\mathrm{WE})$ was far more numerous and diversified than that of RCR, and comprised

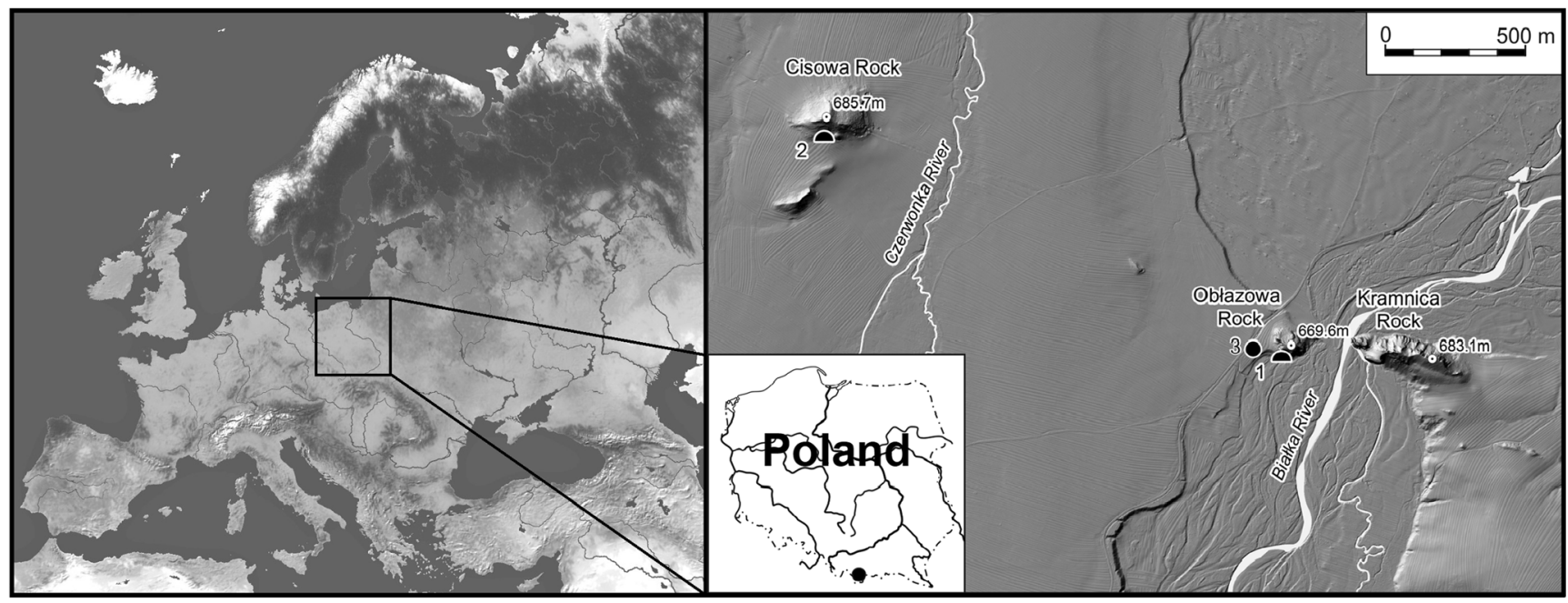

Fig. 2 Locations of Obłazowa Cave (1), Rock overhang in Cisowa Rock (2) and Nowa Biała 1 (3) sites in the Orawa-Nowy Targ Basin (Podhale region), Western Carpathians, Poland 
Fig. 3 a Rock overhang in Cisowa Rock before excavations. b Obłazowa Cave, southern (main) entrance. c Obłazowa Cave, western entrance

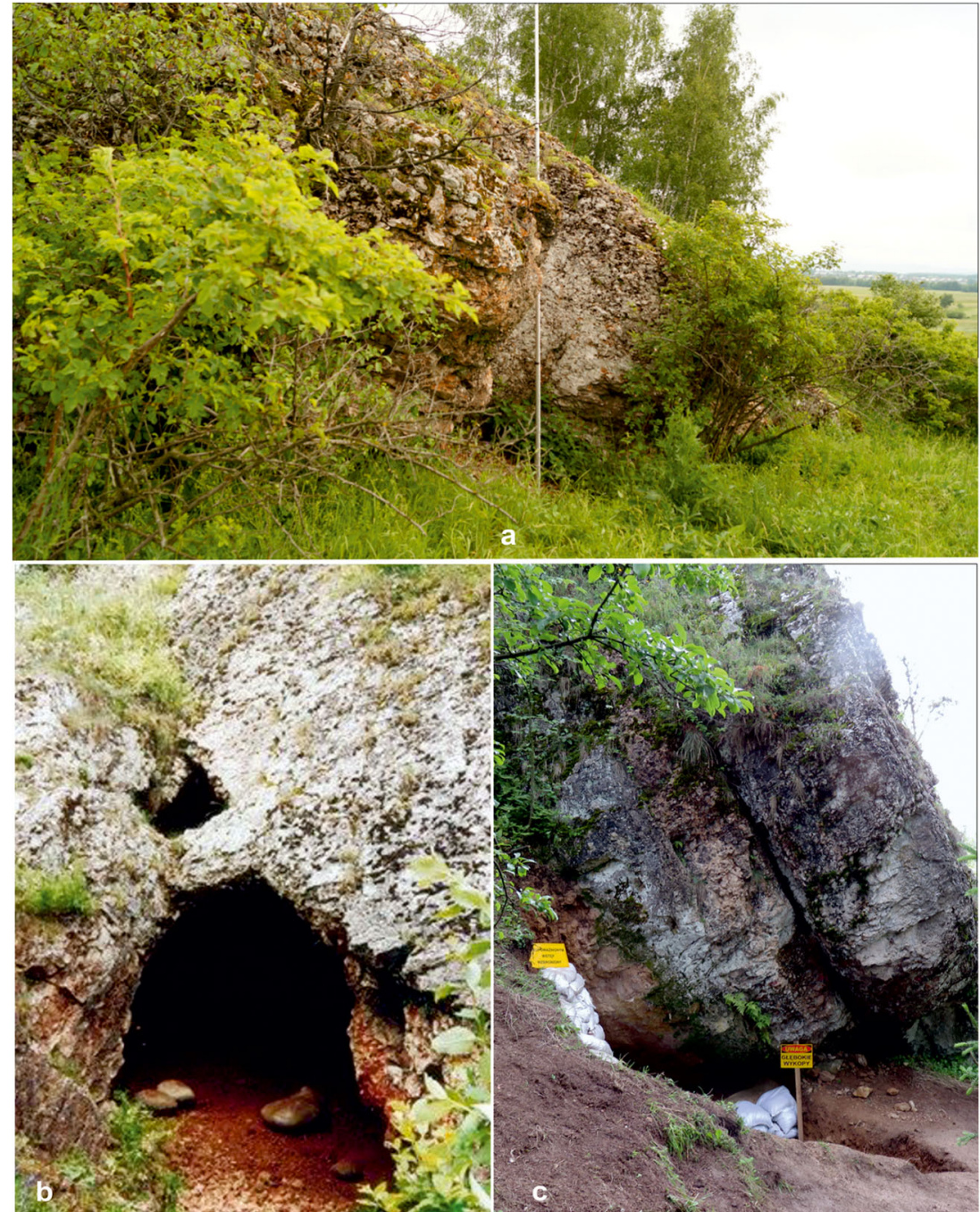

15,053 identified fragments, which correspond to a minimum 5509 individuals, representing at least 120 taxa, including amphibians, reptiles, birds as well as large and small mammals (Table 2, Fig. 4, Supplementary Tables S4, S5 and S6). To estimate changes in biodiversity and compare the small mammal and bird assemblages, we used Simpson's Diversity Index (D) and Margalref's Species Richness Index (d). The statistical analyses of the distributions of individual species in the faunal assemblages were performed in $\mathrm{R}$ package 3.5.1. The remains were identified according to commonly used criteria, specific for every group of vertebrates, while taxonomic attributions and nomenclature followed the most recent and updated classifications. For instance, the generic name for the bank vole was changed from Myodes to Clethrionomys (Kryštufek et al. 2019), and the species name of the Late Pleistocene European narrow-headed vole was changed from Lasiopodomys gregalis to Lasiopodomys anglicus, following recent genetic studies (Baca et al. 2019). Taphonomic studies (traces of digestion and their interpretation) were based on and classified according to methods developed by Andrews (1990) and
Fernández-Jalvo et al. (2016) (the methodological, nomenclature and taphonomic details are described in the Supplementary Material).

\section{Palaeoenvironmental analysis}

In order to reconstruct the environment and landscape in the vicinity of the excavation sites, we used a method that weighted habitats according to the current distributions of small mammal species in different habitat(s) (Evans et al. 1981; Andrews 1990, 2006). The same method was applied for birds. In this approach, each species gets a maximum score of 1 , which is divided among the habitat types according to its habitat preferences (described by the taxonomic habitat index, THI). Habitats were divided into the following six types according to the IUCN (2019): forests, shrublands, grasslands, wetlands, rocky areas and deserts (in this case temperate deserts). The palaeoenvironmental reconstruction of the surroundings of the sites was based on habitat frequencies (expressed as percentages). The proportions of the different 


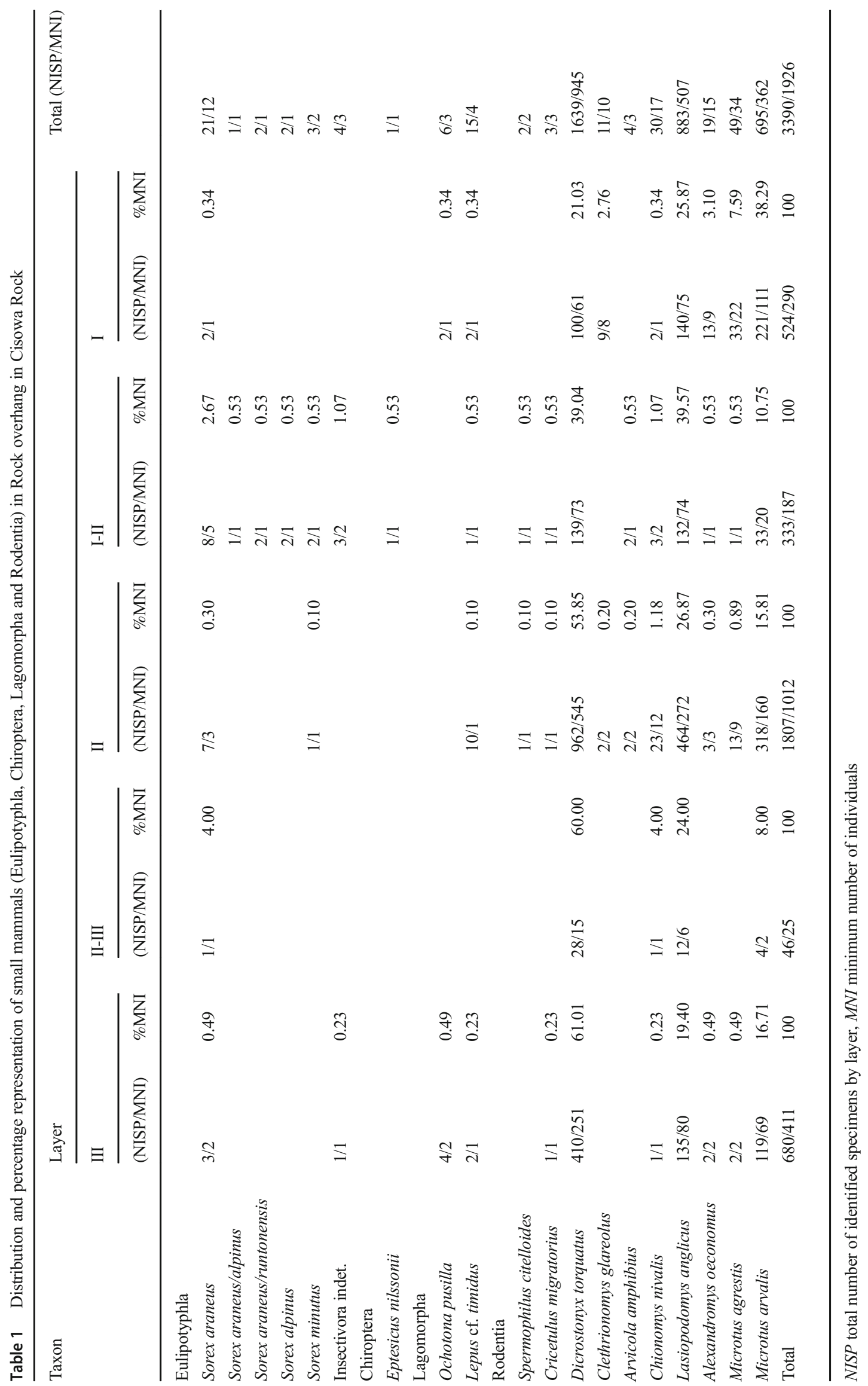




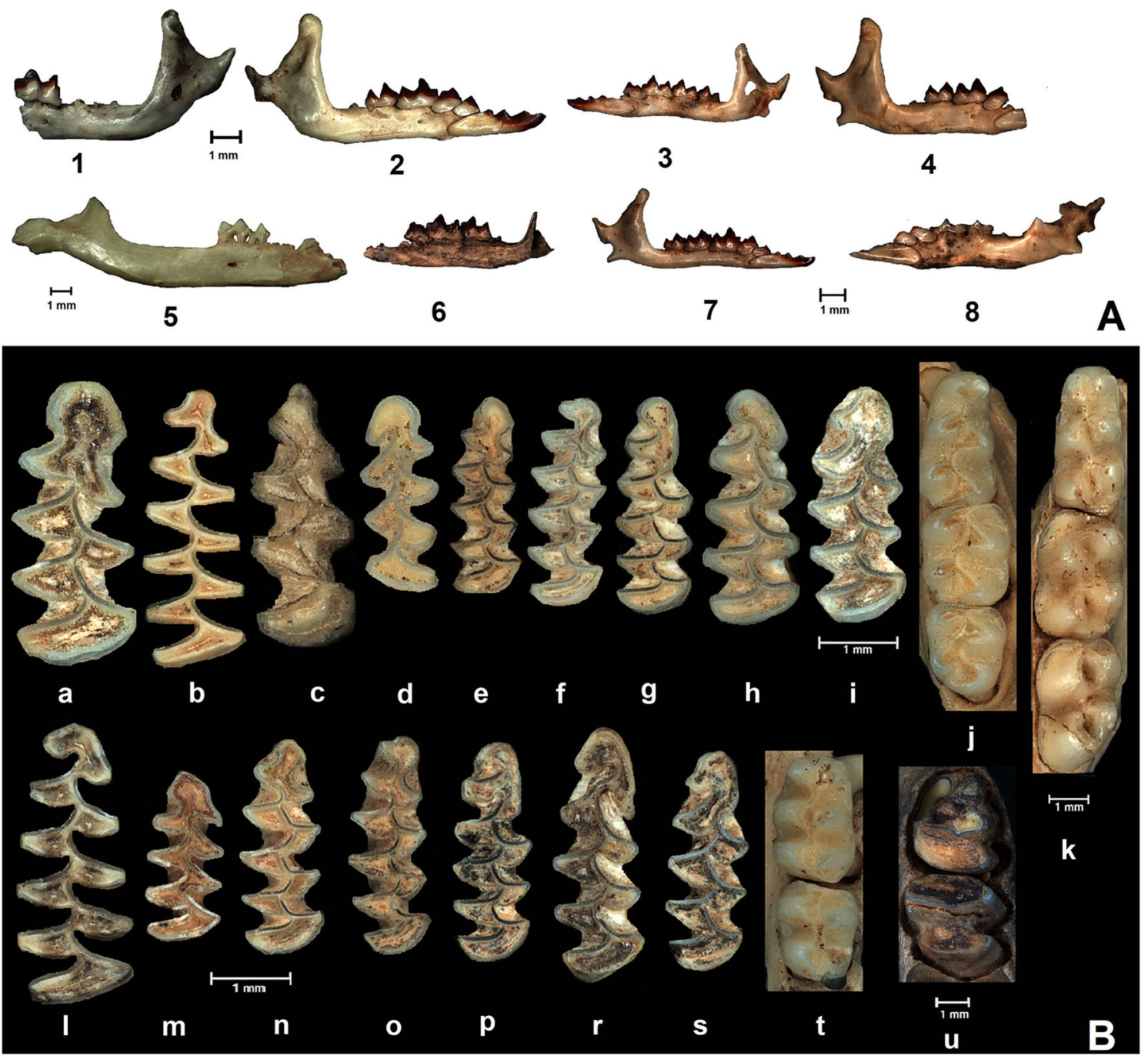

Fig. 4 Small mammal species (Eulipotyphla-A, Rodentia and Lagomorpha-B) from Obłazowa Cave, western entrance [OB(WE)] (1-5, a-k, u) and Rock overhang in Cisowa Rock (RCR) (6-8, 1-t). 1Neomys fodiens; 2 and 6-Sorex araneus; 3 and 7-Sorex minutus; 4 Sorex runtonensis; 5-Talpa europaea; 8-Sorex alpinus; a-Arvicola

amphibius; $\mathrm{b}$ and $\mathrm{l}$-Dicrostonyx torquatus; $\mathrm{c}$-Lemmus lemmus; $\mathrm{d}$ and $\mathrm{m}$-Clethrionomys glareolus; e and $\mathrm{n}$-Microtus arvalis; $\mathrm{f}$ and $\mathrm{o}-$ Microtus agrestis; $\mathrm{g}$ and $\mathrm{p}$-Lasiopodomys anglicus; $\mathrm{h}$ and $\mathrm{r}-$ Chionomys nivalis; $\mathrm{i}$ and $\mathrm{s}-$ Alexandromys oeconomus; $\mathrm{j}$ and $\mathrm{t}-$ Cricetulus migratorius; $\mathrm{k}-$ Cricetus cricetus; $\mathrm{u}$-Ochotona pusilla

habitats at particular sites were expressed as the sum of the given habitat preferences of individual species (Supplementary Tables S7 and S8).

\section{Palaeoclimatic analysis}

It is possible to evaluate local climatic conditions on the basis of the taxonomic composition of the small mammal assemblage assuming that there is a significant correlation between climate and mammal communities. In order to assess climate conditions in the vicinity of the RCR and $\mathrm{OB}(\mathrm{WE})$ sites, we used the qualitative and quantitative bioclimatic models for rodent faunas established by Hernández Fernández (2001a, b, 2006) and developed by Hernández Fernández and Peláez-Campomanes $(2003,2005)$. This method is based on studies of 50 extant sites located in 10 climatic conditions according to Walter's (1970) typology. For each species, the Climatic Restriction Index was established: CRI $=\frac{1}{n}$, where $n$ is the number of climatic zones inhabited by the species. If the species does not occur in a given climate type, the index is assumed to be 0 , and when the species occurs in only one climate type, the index takes the value 1 (Hernández Fernández 2001a, b) (Supplementary Table S9). Based on the CRI values, we derived bioclimatic indices (BC) reflecting the proportions of the various species in each of the ten distinguished climate zones: $\mathrm{BC}=\frac{100 \cdot \sum \mathrm{CRI}}{\mathrm{S}}$, where $S$ is the number of species in the analysed assemblage. The results were used to calculate the discriminant functions of the greatest probabilities of occurrence of the assemblages per climate type (bioclimatic qualitative analysis), and the values of the $\mathrm{BC}$ 
Table 2 Distribution and percentage representation of small mammals (Eulipotyphla, Lagomorpha and Rodentia) in Obłazowa Cave (western entrance)

\begin{tabular}{|c|c|c|c|c|c|}
\hline \multirow[t]{3}{*}{ Taxon } & \multicolumn{4}{|l|}{ Layer } & \multirow[t]{3}{*}{ Total (NISP/MNI } \\
\hline & \multicolumn{2}{|l|}{ III } & \multicolumn{2}{|l|}{ II } & \\
\hline & (NISP/MNI) & $\% \mathrm{MNI}$ & (NISP/MNI) & $\% \mathrm{MNI}$ & \\
\hline \multicolumn{6}{|l|}{ Eulipotyphla } \\
\hline Talpa europaea & $2 / 1$ & 0.03 & $7 / 7$ & 0.39 & $9 / 8$ \\
\hline Sorex araneus & $56 / 32$ & 1.02 & $106 / 56$ & 3.13 & $162 / 88$ \\
\hline Sorex araneus/runtonensis & $32 / 16$ & 0.51 & $47 / 26$ & 1.45 & $79 / 42$ \\
\hline Sorex minutus & $3 / 2$ & 0.06 & $1 / 1$ & 0.06 & $4 / 3$ \\
\hline Sorex runtonensis & $13 / 7$ & 0.22 & $24 / 12$ & 0.67 & $37 / 19$ \\
\hline Sorex sp. & $13 / 9$ & 0.29 & $19 / 13$ & 0.73 & $32 / 22$ \\
\hline Neomys fodiens & $4 / 3$ & 0.10 & $2 / 1$ & 0.06 & $6 / 4$ \\
\hline \multicolumn{6}{|l|}{ Lagomorpha } \\
\hline Ochotona pusilla & $13 / 7$ & 0.22 & $32 / 17$ & 0.95 & $45 / 24$ \\
\hline Lepus cf. timidus & $257 / 9$ & 0.29 & $159 / 5$ & 0.28 & $416 / 14$ \\
\hline \multicolumn{6}{|l|}{ Rodentia } \\
\hline Sciurus vulgaris & & & $2 / 2$ & 0.11 & $2 / 2$ \\
\hline Spermophilus superciliosus & $1 / 1$ & 0.03 & $1 / 1$ & 0.06 & $2 / 2$ \\
\hline Glis glis & $1 / 1$ & 0.03 & $6 / 4$ & 0.22 & $7 / 5$ \\
\hline Sicista betulina & $3 / 2$ & 0.06 & $4 / 4$ & 0.22 & $7 / 6$ \\
\hline Cricetulus migratorius & $13 / 7$ & 0.22 & $7 / 4$ & 0.22 & $20 / 11$ \\
\hline Cricetus cricetus & $17 / 9$ & 0.29 & $19 / 10$ & 0.55 & $36 / 19$ \\
\hline Lemmus lemmus & $1 / 1$ & 0.03 & $2 / 2$ & 0.11 & $3 / 3$ \\
\hline Dicrostonyx torquatus & $1842 / 944$ & 30.08 & $618 / 317$ & 17.71 & $2460 / 1261$ \\
\hline Clethrionomys glareolus & $12 / 6$ & 0.19 & $16 / 8$ & 0.44 & $28 / 14$ \\
\hline Arvicola amphibius & $42 / 26$ & 0.83 & $36 / 18$ & 1.01 & $78 / 44$ \\
\hline Chionomys nivalis & $181 / 96$ & 3.06 & $118 / 68$ & 3.80 & $299 / 164$ \\
\hline Lasiopodomys anglicus & $1663 / 848$ & 27.03 & $923 / 475$ & 26.55 & $2586 / 1323$ \\
\hline Alexandromys oeconomus & $108 / 66$ & 2.10 & $101 / 55$ & 3.07 & $209 / 121$ \\
\hline Microtus agrestis & $182 / 132$ & 4.21 & $113 / 74$ & 4.13 & $295 / 206$ \\
\hline Microtus subterraneus & $1 / 1$ & 0.03 & $3 / 2$ & 0.11 & $4 / 3$ \\
\hline Microtus arvalis & $1744 / 912$ & 29.07 & $1205 / 608$ & 33.97 & $2949 / 1520$ \\
\hline Total & $6204 / 3138$ & 100 & $3571 / 1790$ & 100 & $9775 / 4928$ \\
\hline
\end{tabular}

NISP total number of identified specimens by layer, $M N I$ minimum number of individuals index for each of the 10 climatic zones were used to reconstruct 11 climatic indices using multiple linear regression; for details, see Hernández Fernández and Peláez-Campomanes (2003, 2005).

\section{Genetic analyses}

We analysed ancient DNA to estimate the demographic history of the common vole (Microtus arvalis), a dominant species in all our fossil assemblages. We used mtDNA sequences obtained from specimens from analysed sites to reconstruct changes in effective female population size $\left(N e_{f}\right)$ over time. The effective population size corresponds to the number of mating individuals in an idealized population that behaves in terms of genetic drift in the same way as the actual population analysed. This parameter is commonly used to track demographic changes in populations (Mourier et al. 2012).

Experimental work was performed in a laboratory dedicated to working with ancient DNA at the Centre of New Technologies, University of Warsaw, Poland. Sixty-three mandibles with molars or isolated molars of the common vole (Microtus arvalis) were used for the genetic analyses. Nineteen samples were selected from layer II of RCR; 21 and 20 specimens were selected from layers III and II of OB(WE), respectively (Supplementary Table S10). Additionally, teeth of three present-day common voles found in owl pellets collected in the vicinity of the RCR were analysed. Before DNA extraction, samples were rinsed with sterile water and crushed in sterile tubes. DNA from single rodent teeth was extracted according to Dabney et al. (2013) 
and converted in double-indexed sequencing libraries using a modified protocol of Meyer and Kircher (2010). Hybridization capture was performed following Horn (2012) using mtDNA of present-day common (Microtus arvalis) and field voles (Microtus agrestis) as bait. Enriched libraries were sequenced on a NextSeq Illumina platform using a $2 \times 75$ cycles mode. After sequencing, reads were trimmed and collapsed using AdapterRemoval (Lindgreen 2012). The reads were mapped to the $M$. arvalis mtDNA sequence (NC_038176.1) and only those reads with a mapping quality over 30 and longer than 30 bp were retained. Duplicates were removed; variants and consensus sequences were called using samtools and bcftools (Li et al., 2009). The majority of samples had sequence alignments with regions where two different sequences mapped to the same reference sequence. This was most probably a result of sequencing of nuclear sequences of mitochondrial origin (pseudogenes/numts) alongside real mitochondrial sequences (Triant and DeWoody 2008). For further analysis, we chose a $4.3 \mathrm{~kb}$ long fragment between positions 12,000 and 16,285, a region to which only 1 sequence mapped in all samples. To investigate the phylogenetic position of the studied individuals and to determine to which common vole mtDNA lineage they belong, we reconstructed a Bayesian phylogeny using 303 mtDNA cytochrome $b$ haplotypes (1050 bp) from present-day common voles from various regions of Europe (Supplementary Fig. S1).

To reconstruct changes in $\mathrm{Ne}_{\mathrm{f}}$ of $M$. arvalis, we used the Bayesian SkyGrid method implemented in Beast 1.8.4 and Tracer 1.7 (Drummond et al. 2012, Rambaut et al. 2018). The temporal breadth of the analysed post-LGM samples was too small to reliably estimate the mutation rate in the analysed mtDNA fragment; thus, we recalculated the phylogeny using sequences from three present-day specimens and used the resulting mutation rate in the final calculation. Detailed procedures are described in the Supplementary Material section.

\section{Radiocarbon dating}

Radiocarbon dating of ten samples was carried out in Poznań Radiocarbon Laboratory (Poz) (Goslar et al. 2004) and Beta Analytic (Beta) Miami, using accelerator mass spectrometry. Taxonomically identified bone fragments or teeth were selected for the dating. In one case, a charcoal piece from the fireplace was also dated (Valde-Nowak et al. 2018). The extracted bone collagen in Poznań Radiocarbon Laboratory was ultrafiltered on pre-cleaned Vivaspin 15 MWCO $30 \mathrm{kD}$ filters (Bronk Ramsey et al. 2004). There was enough collagen for dating; the quality of collagen was assessed on the basis of $\mathrm{C} /$ $\mathrm{N}$ atomic ratio and was in all cases rather low, but acceptable (interval of acceptance: 2.7-3.5; Table 3). Measurements of $\% \mathrm{C}$ and $\% \mathrm{~N}$ were always high $(39.8-51.6 \%$ and $14.7-18.9 \%$, respectively). The obtained radiocarbon ages were calibrated in OxCal 4.2.4 (Bronk Ramsey 2017) using the IntCal13 radiocarbon atmospheric calibration curve (Reimer et al. 2013).

\section{Results}

The vertebrate fauna of the Rock overhang in Cisowa Rock is sufficiently diverse and abundant to document faunistic changes in the studied profile. Radiocarbon dates obtained for layer II indicated that fauna accumulated during GS-2, a cold phase (ca. 17.0-16.3 ka) (Table 3; Fig. 5). The fossil assemblages preserved in layers III and II (Table 1, Supplementary Tables S1, S2 and S3) were generally similar and were combined in further analyses; however, the species composition of the uppermost layer I differed from that of the deeper layers. Layer I contained high proportions of recent humus and loose big particles of limestone rubble with small amounts of sediment filling the gaps between them. Therefore, there is a high probability that the fossil assemblage was contaminated by younger remains of the Holocene or recent age. Most probably, several species of the identified forest birds (Coccothraustes coccothraustes, Chloris chloris and Turdus cf. philomelos) (Supplementary Table S2) and some highly represented species of rodents (e.g. Microtus arvalis and Clethrionomys glareolus) (Table 1) did not belong to the Late Pleistocene assemblage. Because of the uncertain stratigraphic situation and the observed inconsistency in the species composition, the fauna from layer I was excluded from further analyses. The fauna found in layers III and II was dominated by tundra-steppe and boreal species, a vertebrate community characteristic of the end of the Late Pleistocene. During the deposition of layers III and II, the landscape surrounding the site showed periglacial features. It was mainly open, partly covered by wetlands and probably had scarce patches of shrubs or small trees. In general, the RCR small mammal fauna was distinctly less diverse $(D=$ 0.60 and $d=1.79$, Supplementary Table S11) than that of $\mathrm{OB}(\mathrm{WE})$.

The faunal assemblages of layers III and II in OB(WE) were much more diverse and abundant than in those from RCR (Table 2, Supplementary Tables S4, S5 and S6). In total, the number of determined specimens in layer III (NISP = $8948, \mathrm{MNI}=3422$ ) was higher than in layer II (NISP = $6105, \mathrm{MNI}=2087$ ), while the number of taxa was almost the same (ca. 89 and 86 taxa, respectively). According to AMS radiocarbon dating, layer III was older and accumulated at the end of GS-2a, between ca. 16.1 ka cal BP and $15.7 \mathrm{ka}$ cal BP (95.4\% range), while layer II mainly during GI-1e (Bølling), between ca. 14.7 ka cal BP and $14.0 \mathrm{ka} \mathrm{cal}$ $\mathrm{BP}$, although the median of the start date (ca. 14.9 ka cal BP) for layer II falls just before the $14.7 \mathrm{ka}$ cal BP warming 
Table 3 Radiocarbon dates from Obłazowa Cave (western entrance) [OB(WE)] and Rock overhang in Cisowa Rock [RCR]. C/N (in coll.) —atomic ratio of $\mathrm{C}$ and $\mathrm{N}$ in extracted collagen

\begin{tabular}{|c|c|c|c|c|c|c|c|c|c|}
\hline \multirow[t]{2}{*}{ Site } & \multirow[t]{2}{*}{ Layer } & \multirow[t]{2}{*}{ Lab code } & \multirow[t]{2}{*}{${ }^{14} \mathrm{C}$ years $\mathrm{BP}$} & \multicolumn{3}{|c|}{ Cal. years BP } & \multirow[t]{2}{*}{ Material Dated } & \multirow{2}{*}{$\begin{array}{l}\mathrm{C} / \mathrm{N} \\
\text { (in coll.) }\end{array}$} & \multirow[t]{2}{*}{ Reference } \\
\hline & & & & $95.4 \% \mathrm{r}$ & ange & Median & & & \\
\hline $\mathrm{OB}(\mathrm{WE})$ & II & Poz-75018 & $12,020 \pm 90$ & 14,120 & 13,704 & 13,881 & Charcoal (fireplace) & - & Valde-Nowak et al. 2018 \\
\hline $\mathrm{OB}(\mathrm{WE})$ & II & Beta-519869 & $12,160 \pm 30$ & 14,162 & 13,928 & 14,051 & Cricetus cricetus mandible & 3.3 & This paper \\
\hline $\mathrm{OB}(\mathrm{WE})$ & II & Beta-517740 & $12,330 \pm 40$ & 14,628 & 14,099 & 14,288 & $\begin{array}{l}\text { Rangifer tarandus fragm. } \\
\text { of naviculocuboid bone }\end{array}$ & 3.2 & This paper \\
\hline $\mathrm{OB}(\mathrm{WE})$ & II & Poz-38123 & $12,340 \pm 80$ & 14,815 & 14,055 & 14,376 & Equus ferus navicular bone & 2.7 & $\begin{array}{l}\text { Nadachowski and } \\
\text { Valde-Nowak } 2015\end{array}$ \\
\hline $\mathrm{OB}(\mathrm{WE})$ & II & Beta-517742 & $12,600 \pm 40$ & 15,155 & 14,727 & 14,972 & Microtus arvalis mandibles & 3.3 & This paper \\
\hline $\mathrm{OB}(\mathrm{WE})$ & III & Beta-517741 & $13,200 \pm 40$ & 16,044 & 15,702 & 15,865 & Lepus cf. timidus pelvis & 3.2 & This paper \\
\hline $\mathrm{OB}(\mathrm{WE})$ & III & Poz-32453 & $13,210 \pm 80$ & 16,140 & 15,614 & 15,877 & $\begin{array}{l}\text { Rangifer tarandus medial } \\
\text { phalanx }\end{array}$ & 2.8 & $\begin{array}{l}\text { Nadachowski and } \\
\text { Valde-Nowak } 2015\end{array}$ \\
\hline RCR & II & Poz-88367 & $13,660 \pm 70$ & 16,770 & 16,229 & 16,471 & Lepus cf. timidus pelvis & 2.8 & This paper \\
\hline RCR & II & Poz-98269 & $13,680 \pm 70$ & 16,800 & 16,250 & 16,501 & cf. Rangifer tarandus molar & 2.7 & This paper \\
\hline RCR & II & Poz-98268 & $13,780 \pm 80$ & 16,965 & 16,360 & 16,663 & Equus ferus bone fragment & 2.7 & This paper \\
\hline
\end{tabular}

(Table 3; Fig. 5). In general, the small mammal assemblage in layer III was less diverse $(D=0.75, d=2.86)$ than that in the younger layer II $(D=0.50 ; d=3.20)$, although species of layer III were more equally distributed than in layer II (Supplementary Table S11).

\section{Taphonomic analysis}

In the analysed material from the Rock overhang in Cisowa Rock, traces of digestion were found on $43 \%$ of incisors and $49 \%$ of first lower molars (Supplementary Table S12). Most of the traces belonged to the light and moderate categories. The percentage of small mammal teeth from RCR showing digestion marks and their degree of alteration point towards a category 3 predator as defined by Andrews (1990). These results indicate two possible nocturnal birds of prey, the eagle owl (Bubo bubo) or tawny owl (Strix aluco). Snowy owl (Bubo scandiacus), which according to Royer et al. (2019) also belongs to the third category of predators, could also be a potential predator. Remains of Strix aluco were found in the sediments of this site. Strix aluco could have been a predator and a prey of an eagle owl. Based on the remains found, this issue cannot be clearly resolved. In contrast to RCR, there were fewer traces of etching on incisors and $\mathrm{m} 1 \mathrm{~s}$ in the material from $\mathrm{OB}$ (WE). In layer III, traces of digestion were found on $30.5 \%$ incisors and $10.5 \% \mathrm{~m} 1 \mathrm{~s}$, while in layer II, they were found on $37 \%$ incisors and $6.7 \% \mathrm{~m} 1 \mathrm{~s}$. Just like in RCR, most of the traces of digestion in $\mathrm{OB}(\mathrm{WE})$ belonged to the light category. Based on traces of digestion of incisors and $\mathrm{m} 1 \mathrm{~s}$, it can be assumed that the potential predator was the great grey owl (Strix nebulosa), which fall into the second category by Andrews (1990). The results also indicate that the accumulation of digested teeth was associated with a predator that shows a specific prey consumption pattern. Despite this, the palaeoecological interpretation based on the relative abundance of the small mammal species is a reliable indication of the habitat where predators consumed their prey.

\section{Comparison of faunal changes in the study area}

To verify how the global warming affected local fauna, we compared changes in the percentage occurrences of small mammal species in assemblages from three successive time periods represented by RCR layers III-II, OB(WE) layer III and $\mathrm{OB}(\mathrm{WE})$ layer II. The first transition occurred from the RCR layers to $\mathrm{OB}(\mathrm{WE})$ layer III, much earlier than the global warming peak between GS-2a and GI-1e, at $14.7 \mathrm{ka}$. The second shift was from $\mathrm{OB}(\mathrm{WE})$ layers III to II, which were chronologically separated by this climatic event. Figure 6 shows the results for the species that had statistically significant differences in at least one comparison between the assemblages (Table 4). Regardless of the percentage measure, $\%$ NISP or $\% \mathrm{MNI}$, there were clear changes in the species distributions visible not only between layers III and II of $\mathrm{OB}(\mathrm{WE})$ but also before this time, i.e. between the periods recorded in RCR layers III-II, and OB(WE) layer III. Furthermore, the changes showed the same uniform trend over time. With the exception of the collared lemming (Dicrostonyx torquatus), the contribution of almost all species increased from the oldest to the youngest layers. It should be emphasized that the change is generally larger between the assemblages of RCR layers III-II and OB(WE) layer III than between layers III and II of $\mathrm{OB}(\mathrm{WE})$. The frequencies of some species, e.g. Arvicola amphibius, Chionomys nivalis, Lasiopodomys anglicus, Lepus cf. timidus and Microtus agrestis, did not show significant changes at the time of the 
Fig. 5 Radiocarbon dates from the studied sites plotted against the NGRIP $\delta^{18} \mathrm{O}$ record (upper panel). GS Greenland Stadials, $G I$ Greenland Interstadials. Bayesian reconstruction of changes in effective population size $\left(\mathrm{Ne}_{\mathrm{f}}\right)$ of the common vole (Microtus arvalis) (lower panel)

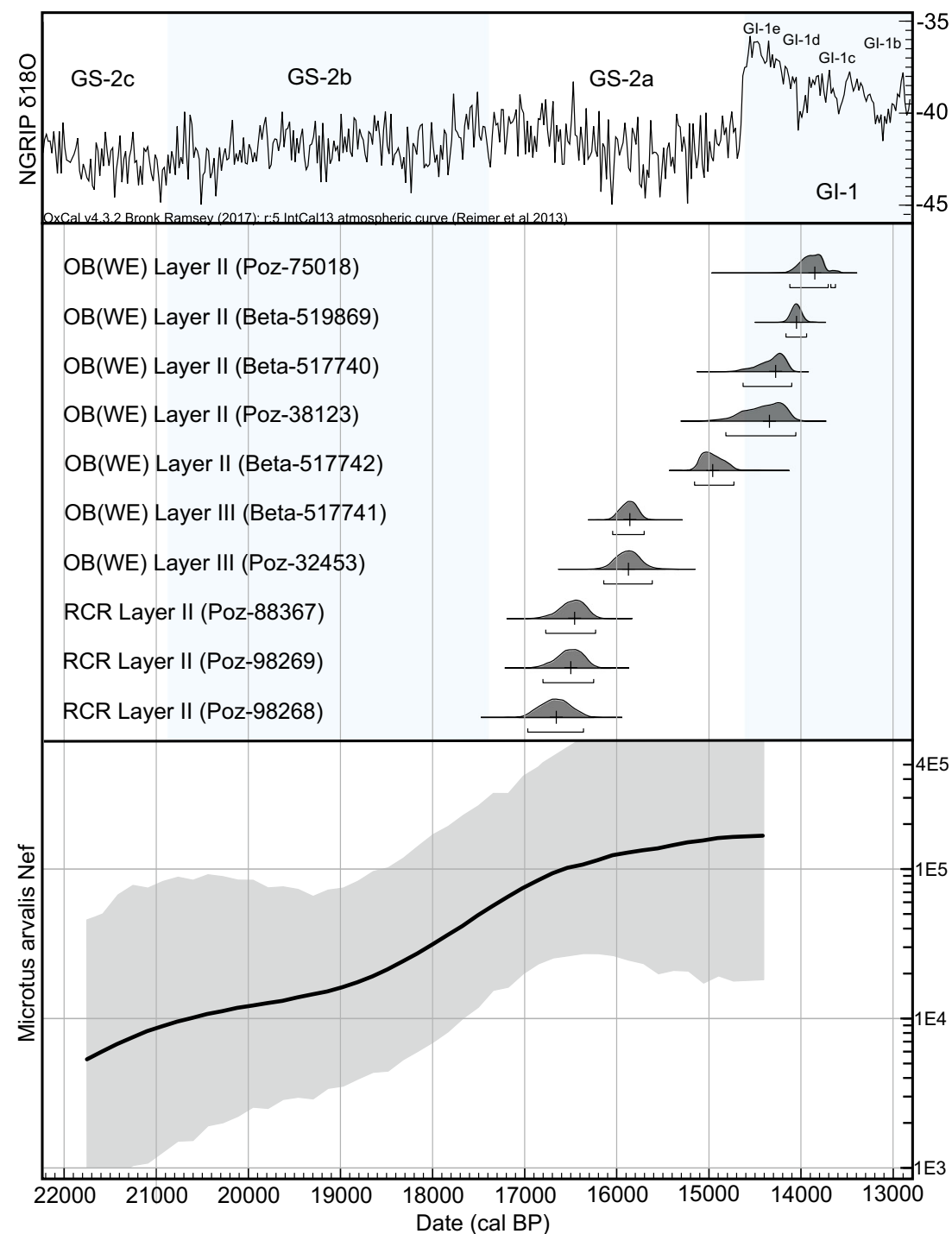

14.7 ka climate change but did show significant increases in the previous period.

We also expressed the changes in the faunal assemblages between the studied periods by summing the absolute differences between the percentage occurrences of individual species in the assemblages. For the small mammals preserved in RCR layers III-II and OB(WE) layer III, this measure based on $\%$ NISP and $\%$ MNI was $25.6 \%$ and $26.0 \%$, respectively, while for the assemblages recorded in layers III and II of $\mathrm{OB}(\mathrm{WE})$ it was $13.4 \%$ and $13.0 \%$, respectively. This implies that the faunal turnover in the period before the global warming in GS-2a/GI-1e was twice as high as during the abrupt global climate change.

We applied the same procedure to avian assemblages. Due to poor representation of individual bird species, statistically significant differences were found only in a few cases (Supplementary Tables S2 and S5). Interestingly, they are all related to differences between the avifauna found in RCR layers III-II and $\mathrm{OB}(\mathrm{WE})$ layer III. In terms of \%NISP, remains of Gallinago media, Strix aluco, Alauda arvensis, Pluvialis apricaria, Alaudidae indet. and Charadriiformes indet. were more abundant in the deposits of RCR than in those of OB(WE) layer III. In the latter site, only Galliformes indet. (of Lagopus size) relatively dominated. No statistically significant differences were observed between $\mathrm{OB}(\mathrm{WE}) \mathrm{II}$ and III layers in this respect. These results are consistent with the sums of the absolute differences in the frequencies of individual species between these assemblages. These measures calculated for the avifauna excavated from RCR layers III-II and OB(WE) layer III are substantially larg$\operatorname{er}\left(A_{N I S P}=60.2 \%, A_{M N I}=73.4 \%\right)$ than those calculated for the faunal assemblages found in layers III and II of $\mathrm{OB}(\mathrm{WE})$ $\left(A_{N I S P}=10.0 \%, A_{M N I}=21.0 \%\right)$.

We also observed a statistically significant change in the percentage NISP between RCR layers III-II and OB(WE) layer III for Rana temporaria, Vipera berus and Anguis fragilis. 

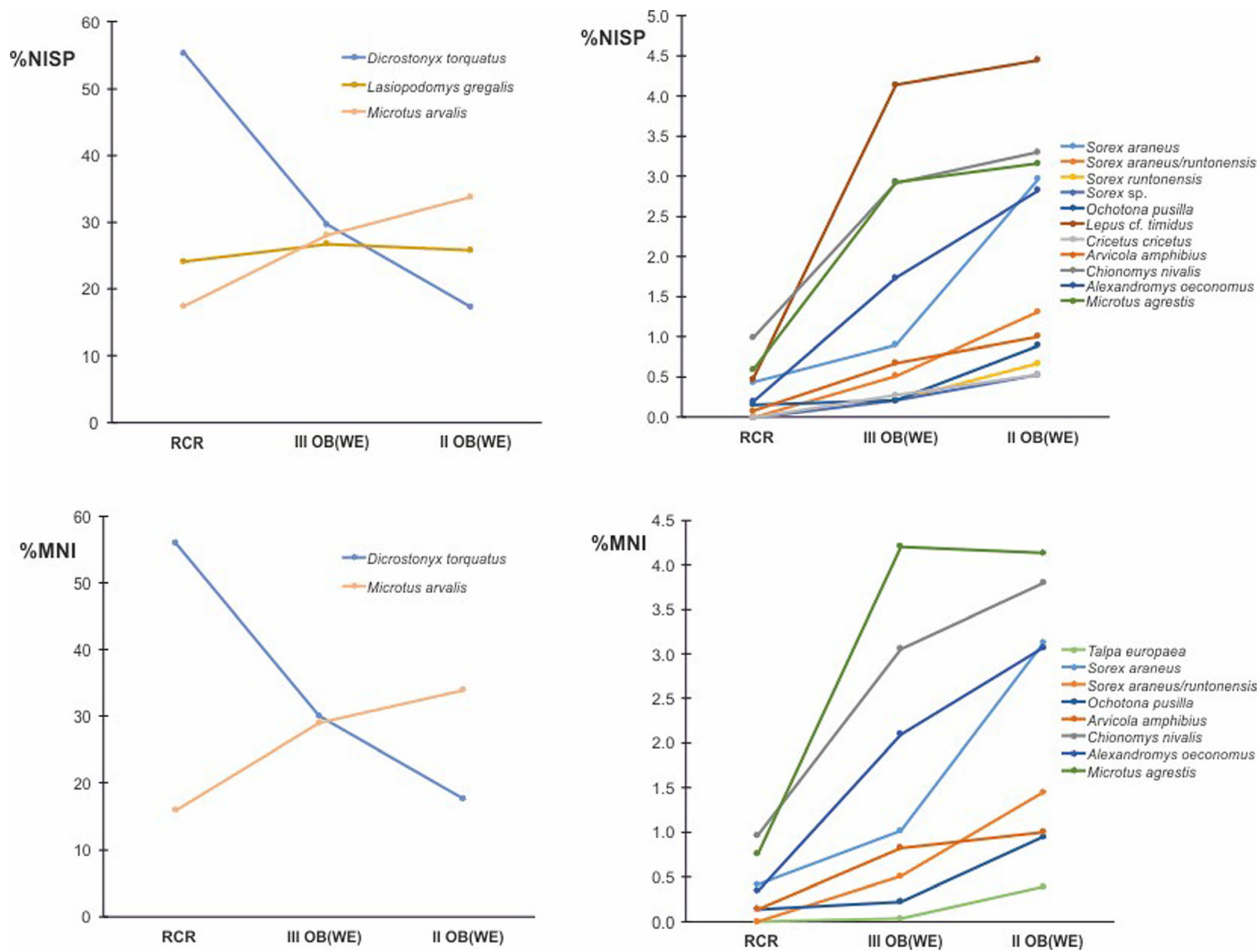

Fig. 6 Changes in the percentage occurrences (expressed in \%NISP and \%MNI) of individual species of small mammals in the Rock overhang in Cisowa Rock (RCR) and Obłazowa Cave, western entrance, OB(WE), layer III and layer II

The contribution of Rana temporaria increased with time, whereas the reptiles decreased (Supplementary Tables S1 and S4). The layers of $\mathrm{OB}(\mathrm{WE})$ did not differ significantly in terms of the distributions of amphibians and reptiles. In RCR layers III-II and OB(WE) layer III, the measures $\left(A_{N I S P}=54.1 \%, A_{M N I}=25.5 \%\right)$ were still bigger for this fauna type than those in layers III and II of OB(WE) $\left(A_{N I S P}=2.9 \%\right.$, $\left.A_{M N I}=16.1 \%\right)$.

\section{Palaeoenvironmental reconstruction}

The analyses of the landscape preferences of small mammals and birds indicated that the reconstructed environments were open areas with small patchy forests (Fig. 7a, b). There were some differences in the relative proportions of habitats between the compared sites reconstructed on the basis of small mammal and bird assemblages (Fig. 7a, b; Supplementary Tables S7 and S8). These differences seem to have been pronounced in the case of wetlands. The remains of small mammals indicated that the share of this habitat decreased slightly over time between layers III (15\%) and II (14\%) of $\mathrm{OB}(\mathrm{WE})$. However, the opposite trend was observed on the basis of birds' remains. The contribution of wetlands increased from $27 \%$ in RCR layers to $29 \%$ in $\mathrm{OB}(\mathrm{WE})$ layer II. Reconstruction of the environment based on the remains of birds and small mammals showed that there was an increase in forests areas over time. The growth of forests was gradual and started before the abrupt warming at ca. $14.7 \mathrm{ka}$ (Fig. 7a, b). Based on the environmental preferences of small mammals, a gradual increase in the share of forests at the expense of grasslands could be observed, although the former never outgrew the latter and equalized in the OB(WE) II layer. The share of forests increased from $25 \%$ in RCR layers to $29 \%$ in the OB(WE) II layer. At the same time, the grassland contribution dropped from 33 to $29 \%$ in the respective sites (Fig. 7a). The shrubland contribution increased from $20 \%$ in RCR layers to $22 \%$ in OB(WE) layer III and then decreased to $21 \%$ in $\mathrm{OB}(\mathrm{WE})$ layer II. Contribution of other landscapes did not 
Table 4 Adjusted $p$ values of the proportion test comparing the contribution of small mammal species expressed by \%NISP and \%MNI in three successive time periods represented by Rock overhang in Cisowa Rock (RCR) layers II to III, Obłazowa Cave, western entrance [OB(WE)] layer III and layer II. The values smaller than 0.05 were bolded

\begin{tabular}{|c|c|c|c|c|}
\hline \multirow[t]{2}{*}{ Species } & \multicolumn{2}{|c|}{ RCR vs. III OB(WE) } & \multicolumn{2}{|c|}{ OB(WE) III vs. II } \\
\hline & $\%$ NISP & $\% \mathrm{MNI}$ & $\%$ NISP & $\% \mathrm{MNI}$ \\
\hline Talpa europaea & 1 & 1 & 0.065 & 0.034 \\
\hline Sorex araneus & 0.073 & 0.169 & 3.1E-13 & $1.8 \mathrm{E}-06$ \\
\hline Sorex araneus/runtonensis & 0.002 & 0.051 & 1.7E-04 & 0.005 \\
\hline Sorex minutus & 1 & 1 & 1 & 1 \\
\hline Sorex runtonensis & 0.088 & 0.342 & 0.002 & 0.100 \\
\hline Sorex sp. & 0.088 & 0.232 & 0.038 & 0.125 \\
\hline Neomys fodiens & 0.730 & 1 & 1 & 1 \\
\hline Ochotona pusilla & 1 & 1 & $1.9 E-05$ & 0.005 \\
\hline Lepus cf. timidus & $3.3 \mathrm{E}-18$ & 1 & 0.654 & 1 \\
\hline Sciurus vulgaris & NA & NA & 0.460 & 0.437 \\
\hline Spermophilus citelloides & 0.893 & 1 & NA & NA \\
\hline Spermophilus superciliosus & 1 & 1 & 1 & 1 \\
\hline Glis glis & 1 & 1 & 0.058 & 0.293 \\
\hline Sicista betulina & 0.893 & 1 & 0.638 & 0.437 \\
\hline Cricetulus migratorius & 0.523 & 1 & 1 & 1 \\
\hline Cricetus cricetus & 0.045 & 0.232 & 0.133 & 0.412 \\
\hline Lemmus lemmus & 1 & 1 & 0.748 & 0.879 \\
\hline Dicrostonyx torquatus & $3.4 \mathrm{E}-110$ & $1.26 \mathrm{E}-61$ & $1.69 \mathrm{E}-40$ & $3.6 \mathrm{E}-20$ \\
\hline Clethrionomys glareolus & 0.597 & 1 & 0.087 & 0.397 \\
\hline Arvicola amphibius & 0.002 & 0.040 & 0.189 & 0.879 \\
\hline Chionomys nivalis & 4.4E-07 & 1.3E-04 & 0.460 & 0.397 \\
\hline Lasiopodomys anglicus & 0.029 & 0.245 & 0.460 & 0.968 \\
\hline Alexandromys oеconomus & $6.4 \mathrm{E}-08$ & 8.4E-05 & 0.002 & 0.125 \\
\hline Microtus agrestis & 2.4E-10 & 6.4E-09 & 0.702 & 1 \\
\hline Microtus subterraneus & 1 & 1 & 0.460 & 0.879 \\
\hline Microtus arvalis & $2.0 \mathrm{E}-24$ & 2.5E-20 & 4.9E-08 & 0.003 \\
\hline
\end{tabular}

change. The analysis based on bird remains showed an increase in the forest contribution from $14 \%$ in RCR to $19 \%$ in $\mathrm{OB}(\mathrm{WE})$ layer II. The share of open areas increased between RCR (33\%) and OB(WE) layer III (36\%) and then fell in $\mathrm{OB}(\mathrm{WE})$ layer II (31\%) (Fig. 7b). The contribution of shrubland decreased from $22 \%$ in RCR layers to $14 \%$ in $\mathrm{OB}(\mathrm{WE})$ layer III and then increased slightly to $15 \%$ in $\mathrm{OB}(\mathrm{WE})$ layer II. The RCR layers differed from $\mathrm{OB}(\mathrm{WE})$ layers in their greater proportions of shrubland over forest, while $\mathrm{OB}(\mathrm{WE})$ layer II was characterized by a smaller difference in the proportions of grasslands and wetlands than other layers (Fig. 7b).

The bioclimatic indices (BC) calculated for the three environments, associated with RCR layers III-II, OB(WE) layer III and $\mathrm{OB}(\mathrm{WE})$ layer II, showed the largest values for climatic zone VI (Table 5; Supplementary Table S13), characterized by a temperate climate and nemoral broadleaf deciduous forests.
Although this indicates that all three environments were similar, the detailed comparison of $\mathrm{BC}$ indices showed that the environments recorded in layers III and II in $\mathrm{OB}(\mathrm{WE})$ were more similar than those in RCR layers II to III and OB(WE) layer III. This indicates that the abrupt warming at ca. $14.7 \mathrm{ka}$ did not influence the local environment in the studied area substantially more than in the previous period.

\section{Palaeoclimatic reconstructions}

The results of bioclimatic analysis based on the $\mathrm{BC}$ values indicated that rodents found in RCR and in layers III and II from $\mathrm{OB}(\mathrm{WE})$ lived in a typical cold temperate climate of type VI (Table 5; Supplementary Table S13). The accumulation of all compared assemblages took place under similar climatic conditions in a period characterized by relatively small temperature changes; although, as expected, many of the temperature parameters were highest for layer II in OB(WE) (Table 6). The differences in the estimated annual mean temperature $(\mathrm{T})$ did not exceed $0.5{ }^{\circ} \mathrm{C}$. The differences in the mean temperatures of the warmest month (Tmax) were even smaller and did not exceed $0.3{ }^{\circ} \mathrm{C}$. The same was observed in the mean temperatures of the coldest month (Tmin) (differences did not exceed $0.6{ }^{\circ} \mathrm{C}$ ), while the mean annual thermal amplitude (Mta) changed from 22.9 to $22.4{ }^{\circ} \mathrm{C}$. However, differences in the values of annual total precipitation $(\mathrm{P})$ were greater. The RCR assemblage accumulated during a period of relatively small annual total precipitation, while the $\mathrm{OB}(\mathrm{WE})$ assemblage from layer III accumulated in the period with highest total annual precipitation. The environment associated with the RCR layers was also characterized by the longest drought periods.

According to Walter (1970), the mean annual monthly temperature in the temperate, cool and humid climate of type VI is from +7 to $+10^{\circ} \mathrm{C}$, i.e. higher than that reconstructed, which did not exceed $+2.7^{\circ} \mathrm{C}$. In this climate type, the mean annual precipitation is $600-800 \mathrm{~mm}$, which is slightly lower than the estimated values $(847-1012 \mathrm{~mm})$ for the studied area. The reconstructed values of the mean annual monthly temperatures were closer to the temperatures characteristic for the very cool and humid climate of type VIII. In general, the obtained values corresponded to the boreal macroclimate (RivasMartinez and Rivas-Sáenz, 1996-2009), with annual mean temperatures (T) below $+6{ }^{\circ} \mathrm{C}$ and annual positive temperatures ( $\mathrm{Tp}$ ) (expressed as the sum of the mean monthly temperatures of months with average temperatures higher than $0{ }^{\circ} \mathrm{C}$ ) less than $800^{\circ} \mathrm{C}$.

According to the bioclimatic division of the world by Rivas-Martinez and Rivas-Sáenz (1996-2009), bioclimates, thermobioclimates (thermotypes) and ombrotypes can be distinguished within each macrobioclimate. The divisions are based on the differences in precipitation patterns, temperatures and ombrothermal indices. By comparing the results obtained 
Fig. 7 Habitat proportions in the vicinity of the Rock overhang in Cisowa Rock (RCR) and Obłazowa Cave, western entrance (OB (WE), layers III and II reconstructed on the basis of small mammal (a) and bird (b) assemblages
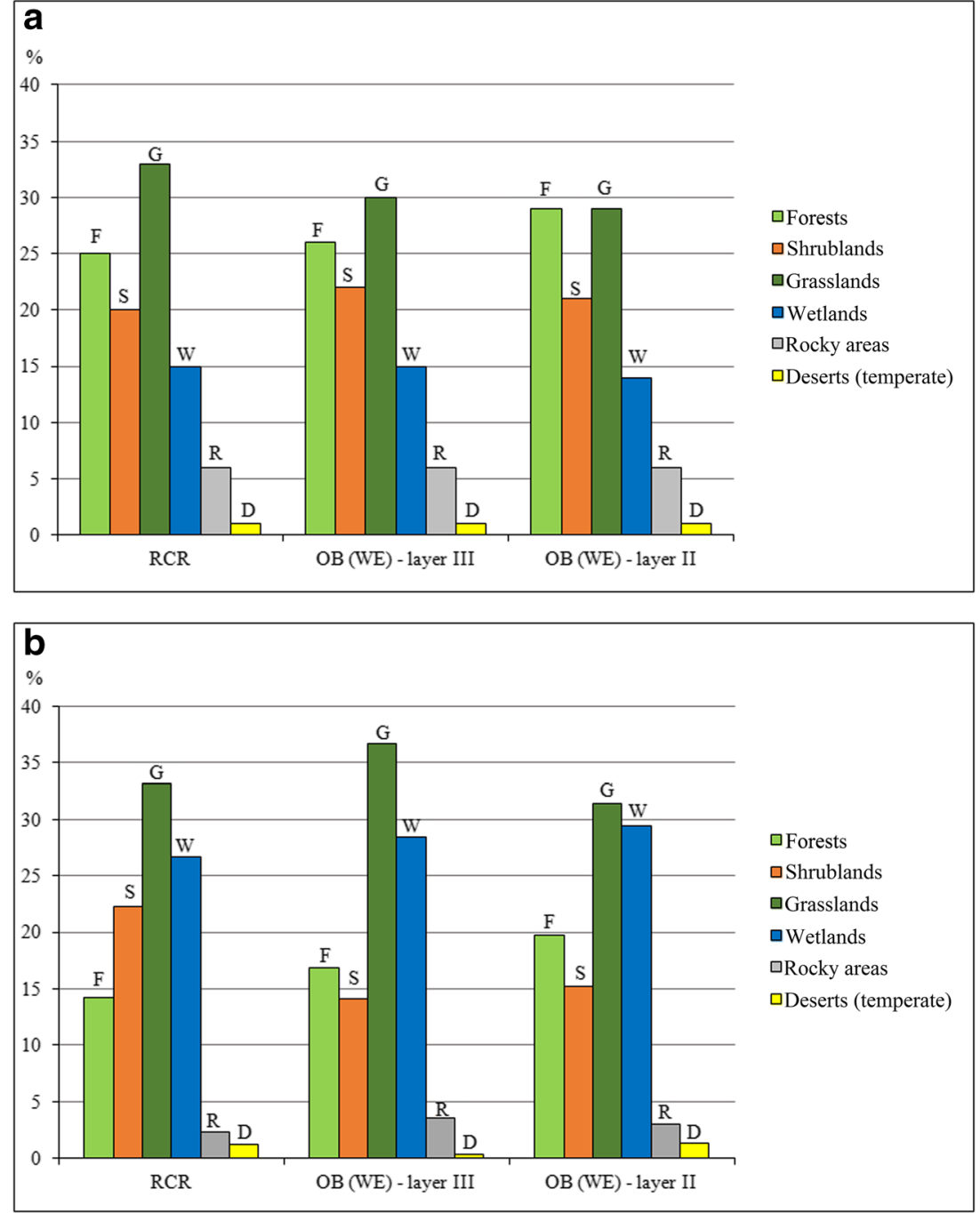

for RCR and $\mathrm{OB}(\mathrm{WE})$ with the data presented by RivasMartinez and Rivas-Sáenz (1996-2009), it is possible to determine a more precise estimate of the climatic variation at the time when the faunal assemblages were deposited. The values of Mta, Tp and T (Table 6) indicated that the rodent assemblages were deposited in the studied sites during a subcontinental bioclimate within a boreal climate. The Tp values also make it possible to specify the thermotype within the climate. Reconstructed $\mathrm{Tp}$ values for the studied sites ranged between 680 and $800{ }^{\circ} \mathrm{C}$ and were characteristic of a thermoboreal climate $(\mathrm{Tb})$. At present, the area corresponding to this thermoclimate, within the boreal macroclimate in Europe, is located between $25^{\circ}$ and $65^{\circ} \mathrm{E}$ and between $51^{\circ}$ and $57^{\circ} \mathrm{N}$ (Rivas-Martinez and Rivas-Sáenz, 1996-2009).

In spite of the general similarity between the inferred palaeoenvironments, there were larger differences between RCR layers III-II and OB(WE) layer III, than between OB(WE) layers III and II. For 9 of the 13 climatic factors, the differences were bigger for the former than the latter. This applies most to thermicity index, winter length, annual total precipitation and drought length. If the global GS-2a/GI1e warming had significantly affected the local environments, we should expect greater differences in the parameters calculated for OB(WE) layers III and II .

\section{Genetic studies}

To reconstruct the changes of the effective population size of common vole over time, we recovered a $4.3 \mathrm{~kb}$ fragment of mtDNA from 51 palaeontological and 3 present-day samples, morphologically determined as belonging to the common vole (Microtus arvalis). Forty-eight specimens were M. arvalis: 15, 18 and 15 of them were from layers II and III from OB(WE) and layer II from RCR, respectively (Supplementary Table S10). To validate the obtained sequences, we checked the amount of deamination at terminal nucleotides of DNA molecules. We also checked whether the ages assigned to mtDNA sequences were congruent with their divergence from the root of the phylogenetic tree (Root-To-Tip analysis). As a result, we discarded seven sequences as probable modern 
Table 5 Values and distribution of bioclimatic index (BC) for Rockshelter in Cisowa Rock (RCR) and Obłazowa Cave (western entrance) $[\mathrm{OB}(\mathrm{WE})]$ assemblages. Climate zones and their main vegetation types: I - equatorial zone, evergreen tropical rain forest; II-tropical zone with summer rains-tropical deciduous forest; II/III-transition tropical semiarid zone, savanna; III—sub-tropical arid zone, sub-tropical desert; IV- winter rain and summer drought zone-sclerophyllous woody plants; Vwarm temperate zone-temperate evergreen forest; VI - typical temperate zone-nemoral broadleaf deciduous forest; VII-arid temperate zonefrom steppe to cold desert; VIII - cold temperate (boreal) zone, boreal coniferous forest (taiga); IX - arctic zone, tundra

\begin{tabular}{|c|c|c|c|c|c|c|c|c|c|c|}
\hline \multirow[t]{2}{*}{ Species } & \multicolumn{10}{|c|}{ Climatic zones } \\
\hline & I & II & $\begin{array}{l}\text { II/ } \\
\text { III }\end{array}$ & III & IV & $\mathrm{V}$ & VI & VII & VIII & IX \\
\hline OB (WE), layer II & 0 & 0 & 0 & 0 & 7.287 & 0 & 40.618 & 15.100 & 21.868 & 15.100 \\
\hline OB (WE), layer III & 0 & 0 & 0 & 0 & 5.553 & 0 & 41.106 & 16.106 & 21.106 & 16.106 \\
\hline RCR layers III and II & 0 & 0 & 0 & 0 & 11.660 & 0 & 34.990 & 12.490 & 21.660 & 19.160 \\
\hline
\end{tabular}

contaminants and three whose divergence from the root was substantially lower than expected at the assigned age (See Supplementary text for the details). The remaining 38 mtDNA sequences were used for reconstructing the effective population sizes. The analysis revealed a nearly 30 -fold increase in the $\mathrm{Ne}_{\mathrm{f}}$ between 22.0 and $14.4 \mathrm{ka}$. The $\mathrm{Ne}_{\mathrm{f}}$ trajectory was not uniform across the entire period. First, there was a nearly four-fold increase between $22.0 \mathrm{ka}$ and around $18.5 \mathrm{ka}$, followed by an even more rapid eight-fold increase up to a value of ca. 165,000 around 14.4 ka (Fig. 5).

\section{Discussion}

The rock overhang in Cisowa Rock and Obłazowa Cave are extraordinary sites located very close to each other, containing layers providing an uninterrupted record of faunal changes in the period from ca. 17.0 to $14.0 \mathrm{ka}$, i.e. from the end of Pleniglacial (GS-2a) to the beginning of Late Glacial (GI-1e, Bølling). This period includes an important event at ca. 14.7 ka, i.e. a global warming. Therefore, the exploration of these sites can help verify the impact of the climate change on local environments. It could be anticipated that there would be a clear relationship between the warming and the fauna preserved in the studied deposits. Specifically, as OB(WE) layer III and $\mathrm{OB}(\mathrm{WE})$ layer II correspond to the periods before and after the global warming, we should expect great differences in the faunal assemblages and bioclimatic parameters associated with these layers. Instead, we found that a faunal transition, increases in the population sizes of selected rodent species and environmental shifts proceeded continuously from ca. $17.0 \mathrm{ka}$ onwards. Furthermore, we found a bigger dissimilarity in the period prior to $14.7 \mathrm{ka}$, i.e. between fauna discovered in RCR layers III-II and OB(WE) layer III, than between OB(WE) layers III and II. The changes appear to have occurred earlier, leading to an increase in biodiversity, as the small mammal (Nadachowski et al. 2003; Rzebik-Kowalska 2003) and bird (Tomek et al. 2003) assemblages discovered in layers IV and V of Obłazowa Cave (main chamber), probably from GS-2b-a (Lorenc 2006), were generally less diverse than those found in layers III and II of $\mathrm{OB}(\mathrm{WE})$ as well as RCR. However, the proportions of species with different habitat preferences were similar in all these layers.

The presented results suggest that local climate changes in the studied region were rather unrelated to global climate changes. Correct stratigraphic recognition and dating of the layers is very important for drawing these conclusions. To dispel any doubts, we dated various fossil remains found in the layers and obtained consistent results. Moreover, we observed no disturbances relating to their deposition. We obtained five congruent, independent datings, allowing us to exclude potential contamination of the $\mathrm{OB}(\mathrm{WE})$ layer II by more recent remains of small mammals that could have indicated that the layer was younger than it really was. It could also be argued that the faunal changes occurred over time intervals of various lengths could have resulted in a greater difference between faunal assemblages in the longer period. In fact, based on the obtained radiocarbon dates (Table 3), the time interval between the average dates for RCR layers III-II and OB(WE) layer III is 674 years (89-1351 years, when considering the $95.4 \%$ range), while for layers III and II of OB(WE) it is 1557 years (459-2436 years). However, we observed larger faunal changes in the former period than in the latter. This indicates that the faunal change before the GS-2a/GI-1e boundary not only had a larger magnitude but also a faster rate.

The correctness of the stratigraphy of the studied layers is supported by conclusions drawn from other faunal assemblages in Poland of similar age. Although there are about dozen or so faunal assemblages in archaeological sites dated to the post-LGM (GS-2a) and/or beginning of Late Glacial (GI-1) (Kowalski, 1989; Madeyska and Cyrek 2002; Stefaniak et al. 2009; Wiśniewski et al. 2017), only Wilczyce (Nadachowski et al. 2014) and Krucza Skała Rock-shelter (Bocheński and Tomek 2004; Nadachowski et al. 2009) yielded sufficient remains of small mammals 
Table 6 Values for the climatic factors estimated by applying quantitative bioclimatic models (Hernández Fernández and Peláez-Campomanes 2003, 2005 ) to rodent assemblages from Rock overhang in Cisowa Rock (RCR) and Obłazowa Cave (western entrance) [OB(WE)]

\begin{tabular}{|c|c|c|c|c|c|c|c|c|c|c|c|c|c|}
\hline Site & $\mathrm{T}$ & $\mathrm{Tp}$ & Tmax & Tmin & Mta & It & Itc & $\mathrm{W}$ & VAP & FVAP & Io & $\mathrm{P}$ & $\mathrm{D}$ \\
\hline OB (WE) layer II & 2.7 & 699 & 14.3 & -8.3 & 22.6 & -139.3 & -82.3 & 3.1 & 4.6 & 4.8 & 14 & 987 & -0.2 \\
\hline OB (WE) layer III & 2.5 & 671.4 & 14.0 & -8.4 & 22.4 & -143.9 & -91.5 & 3.1 & 4.4 & 4.7 & 14.5 & 1012 & -0.3 \\
\hline RCR layers III and II & 2.2 & 726.6 & 14.0 & -8.9 & 22.9 & -94.7 & -94.7 & 3.5 & 4.6 & 4.2 & 13.4 & 847 & 0.4 \\
\hline
\end{tabular}

$T$ annual mean temperature, $T p$ annual positive temperature, Tmax mean temperature of the warmest month, Tmin mean temperature of the coldest month, Mta mean annual thermal amplitude, It thermicity index, Itc compensated thermicity index, $W$ winter length, VAP vegetative activity period, $F V A P$ free vegetative activity period, $I o$ ombrothermic index, $P$ annual total precipitation, $D$ drought length

and birds to make comparisons with the fauna found in the rock overhang in Cisowa Rock and Obłazowa Cave (western entrance). Generally, the fauna described from Wilczyce and the oldest layers of Krucza Skała Rock-shelter (layers I, II and 1,2 ) was very similar to that found in layers II and III of RCR as well as III of $\mathrm{OB}(\mathrm{WE})$, but was less diverse, compared especially with the latter. The differences may have resulted from local conditions, e.g. the landscape morphology, slope exposition to insolation, irrigation, soil type and species of predator responsible for accumulation of the fossil assemblages. These sites are located 150-200 km north of the sites studied here, thus, it is also possible that the lower diversity of Krucza Skała and Wilczyce was associated with their more northern locations and thus their closeness to the ice sheet and more severe conditions in the glacial period. Nevertheless, all results indicated that southern Poland was covered by steppetundra with a small contribution of coniferous and cold deciduous forest during GS-2a. Wong et al. (2020) came to similar conclusions by reconstructing the palaeoenvironment in Swabian Jura (southwestern Germany) based on small mammal remains. Unfortunately, the results obtained cannot be verified by palaeobotanical studies because there is no pollen profile covering a period between 17.0-14.0 ka in southern Poland.

An interesting finding of the presented analyses is that the change in faunal composition between the very cold end of the Pleniglacial (GS-2) and much warmer Bølling (GI-1e) was not as spectacular as expected. The small differences in species compositions between the compared assemblages were too small to be explained by the global climate warming at the $14.7 \mathrm{ka}$ transition. Furthermore, we observed that the faunal and environmental changes started earlier, at least ca. $17.0 \mathrm{ka}$ and gradually continued to ca. $14.0 \mathrm{ka}$.

The local environments may not have responded directly to the global climate changes due to the high resilience of the ecosystems (Holling 1973); this may have been associated with high biodiversity as well as high flexibility of food webs and relationships between the species in these communities. However, our findings indicated that the changes in fauna and environments began over 2000 years before and were even larger than those during the $14.7 \mathrm{ka}$ global warming.
Therefore, this suggests that a climate shift could have occurred in Central Europe (or even possibly over a greater area of Europe) before the ${ }^{18} \mathrm{O}$ isotope changes were recorded in the Greenland glacier at the GS-2a/GI-1e boundary. In fact, it is believed that the main source of moisture for the ice core sites, NGRIP, GRIP and GISP2, was the North Atlantic (Charles et al. 1994; Werner et al. 2000, 2001; Langen and Vinther 2009), which is quite distant from the excavation sites analysed here.

It is not inconceivable that the climatic changes in the region that was the source of snowfall in Greenland at the end of the Pleistocene were later than those in Central Europe. It is also possible that when the fauna and environment were changing in Central Europe, the Greenland glacier was fed with snow formed by water evaporating from regions near the North Pole and thus still depleted in $\delta^{18} \mathrm{O}$ isotope, despite the climate already being warmer in other regions. It is also possible that the successive faunal changes were not driven by temperature oscillations, but changes in other climatic parameters, e.g. precipitation and humidity, which are not directly reflected in $\delta^{18} \mathrm{O}$ records.

The obtained result can also be explained by smaller magnitude of vegetation response to temperature increase in Central Europe (Feurdean et al. 2014) compared to the magnitude of temperature increase suggested by the Greenland oxygen isotope record at $14.7 \mathrm{ka}$ (Renssen and Isarin 2001). Moreover, the magnitude of the climate shift appears to have been less dramatic in more continental Central Europe than in the more oceanic Western Europe (Feurdean et al. 2014; Moreno et al. 2014). In the period between GS-2a / GI-1e, no sudden and drastic changes in the vegetation cover were found on any of the profiles shown by Feurdean et al. (2014). Forests occurred in Central Europe before global warming $14.7 \mathrm{ka}$ that confirms the obtained results. Furthermore, the Western Carpathians may have been a northern LGM refugium, especially for several species of temperate trees (Jamrichová et al. 2017), which probably resulted in the early development of suitable biotopes and increases in population sizes of several mammal species (Sommer and Nadachowski 2006) far in advance of global temperature increases. Forests have their own microclimate and a "buffer-function" that 
soften climate conditions, which could be reflected by smaller and gradual changes in fauna composition pattern. Consequently, the intermediate vertebrate communities comprising a mix of extinct and extant species already existed before the period of global climate warming, whereas coldclimate species were progressively and successively replaced by temperate ones.

\section{Final Palaeolithic in the Western Carpathians}

The remains of Palaeolithic settlements in the Polish Carpathians are scarce, and the scale of research is hardly comparable to investigations conducted in other regions of Poland. In the initial phases of development of archaeology, caves in the Carpathians, even in the Tatra Mts., were treated as potential archaeological sites, e.g. Magura Cave (Jura 1955) and were studied in the same manner as those from regions nowadays considered classical for Polish archaeology, e.g. those from Kraków-Częstochowa Upland. The negative result of the Magura Cave archaeological excavation led archaeologists to abandon further research in this area. Only since the late 1970s, as a result of intensive surveys conducted in the Podhale Region and Pieniny Mts. (Valde-Nowak 1991), has the number of Palaeolithic sites, including those of Magdalenian age, increased. They represent various levels of significance. In the less important category are the surface collections in Koniówka, site 1; Ostrowsko, site 4; Frydman, site 13; Krauszów, site 1; or Szlembark, site 1 (Dryja and Rydlewski 1991; Valde-Nowak et al. 2016). Much more important are Obłazowa Cave (also known as Nowa Biała, site 2) (Valde-Nowak et al. 2003), Sromowce Wyżne-Kąty, site 1 (Valde-Nowak 1991), which are both interpreted as basecamps, and Sromowce Wyżne, a site recognized as a radiolarite workshop (Drobniewicz et al. 1997). A separate group is most probably represented by short-term hunting camps: Dział, site 2 (Rydlewski 1990) and Podczerwone, site 1 (Valde-Nowak 1991). For Palaeolithic hunters, the OrawaNowy Targ Basin was a place with extremely attractive features for settlements (Lanczont et al. 2019). The basin is characterized by a varied topography and diverse geology compared with neighbouring areas, and has typical highland and even para-lowland landscapes, with easily accessible beds of good quality raw materials, especially radiolarite, which occurs in various different colour varieties. The great interest of the Palaeolithic humans in Pieniny radiolarites can be understood as a proxy indicator for the higher value of such local raw materials than, e.g. Kraków-Częstochowa flints.

The first stratified Final Palaeolithic site is Obłazowa Cave (Valde-Nowak et al. 2003, 2018). In the cave chamber, layer III, a small assemblage was found during the first excavation campaigns; in the main publication on the topic (ValdeNowak et al. 2003), the assemblage was discussed as material probably originating from the late phase of the Upper
Palaeolithic or even Late Palaeolithic. Two blade-like endscrapers were found. Two truncations with very fine and slightly oblique cuttings were also found and resembled Magdalenian objects (Valde-Nowak et al. 2003, 67, comp. also 57-59 Fig. 37: 4-8). As the excavations continued, some inventories typical of the Magdalenian cultural environment were discovered. The most important among them were a blade core, a Zinken type perforator, a burin and a sandstone plaque interpreted as a Lalinde-Gönnersdorf figurine (Valde-Nowak et al. 2017). Another Magdalenian assemblage was recently discovered under an overhang at the western entrance to Obłazowa Cave, $\mathrm{OB}(\mathrm{WE})$, in the fireplace of layer II (Valde-Nowak et al. 2018). In light of new data, we can assume that Magdalenian settlers occupied this place at the time layer III inside the cave was formed. Also noteworthy in this context is that an artefact was discovered in layer III of OB(WE) (Nadachowski and Valde-Nowak 2015). Their techno-typological features distinguish them from those discovered in the evidences in layer II (fireplace) of the overhang. However, the question of a possible connection between layer III in the chamber and layer III in the rock overhang is still open. The Palaeolithic sequence of the Obłazowa Cave chamber and western entrance ends in the older part of Allerød. The continuation of the Palaeolithic process of colonization of the vicinity of Obłazowa Rock was documented at the open air Nowa Biała 1 site, located about $100 \mathrm{~m}$ west of the Obłazowa Cave entrance (Lanczont et al. 2019). This site provided nearly two thousand artefacts of the Federmesser culture, one of the groups of the Arch-Backed Points Technocomplex, scattered around the remains of a hut.

\section{Post-LGM hunter-gatherers in Sub-Carpathian Europe}

The area within and around the Western Carpathians is split into three zones with different palaeogeographies, which may help us to understand post-LGM settlement in this area. The first zone is the area north of the Carpathians, which is the zone that was closest to the southern border of the Vistulian (=Weichselian) glacier and successively shifted north as the Leszno, Poznań and Pommeranian glaciation phases proceeded. Therefore, this zone did not favour permanent colonization. In fact, sites dated before the end of GS-2a are not numerous in this area. Taking into account the nature of the known traces of both Magdalenian culture in Maszycka Cave (Kozłowski et al. 2012), and Epigravettien in, e.g. KrakówSpadzista (Kozłowski and Sobczyk 1987), Zawalona Cave in Mników (Alexandrowicz et al. 1992) and Targowisko site 10 11 (Wilczyński 2014), it has been suggested that the two cultural environments coexisted in this territory, although there is no archaeological evidence that could confirm this statement (Wiśniewski et al. 2017). In the first millennia after the LGM, the zone gives the impression that it was a "land that belonged to no one", sporadically visited by hunter groups. The second 
zone encompasses the Western Carpathians. Their northern part, i.e. the Dunajec and Poprad rivers basins, named in this article as the Orawa-Nowy Targ Basin, provide almost no traces that can be considered Epigravettian, aside from the site of Ujazd near Jasło (Valde-Nowak et al. 2006). There are many traces of the Magdalenians in Stará Lubovňa (ValdeNowak et al. 2007), Hłomcza on the San River (ValdeNowak and Muzyczuk 1999), Uście Gorlickie in Lower Beskidy Mts. (Valde-Nowak 2015), as well as the OrawaNowy Targ Basin and Pieniny Mts, which is where the Magdalenian sites are most concentrated. These sites are of different chronology, dated from before the end of GS-2a and after. This shows that Magdalenian groups dominated in the northern part of the Western Carpathian zone. The third, southernmost zone is located in the southern part of the Western Carpathians and Carpathian Basin, to the south of the Orawa-Nowy Targ Basin. Traces of Magdalenian origin are completely absent there, and instead, Epigravettian settlements are present, e.g. at Moravany-Żakovska and Lopata (Hromada and Kozłowski 1995; Kazior et al. 1998), Sagvar (Lengyel 2016), but these sites do not show strong settlement dynamics and are very dispersed over time.

In light of these results, it can be assumed that the OrawaNowy Targ Basin offered favourable conditions for settlement for a long time in the Late Pleistocene, which is demonstrated by the findings in Obłazowa Cave. Therefore, the lack of unambiguous traces of Epigravettian occupation in this cave is intriguing, especially when we consider the clear presence of temporally separate remains of Magdalenian settlements. It is not inconceivable that human groups were too rare and had no opportunity to come across this region before ca. $16.0 \mathrm{ka}$ or that conditions for human settlement in this area were not sufficiently attractive. Intense research in the central Western Carpathians over the last decades has shown the existence of a southern border of the Magdalenian range, which runs through the valley of the upper catchment of the Poprad River. Epigravettian sites, however few, lie south of this zone. The only Epigravettian site in the northwestern Carpathians, from Ujazd, near Jasło, most probably predates the expansion of Magdalenian populations in this zone.

\section{Conclusions}

We examined the impact of the global climatic change that occurred ca. $14.7 \mathrm{ka}$, i.e. during the transition period between the Pleniglacial (GS-2a) and Bølling (GI-1e), on faunal succession at the local scale in the Orawa-Nowy Targ Basin in the Polish Western Carpathians. The study included three radiocarbon dated vertebrate assemblages. Two of them, from the Rock overhang in Cisowa Rock and layer III in Obłazowa Cave (western entrance), were deposited before the global climatic change, and one, from layer II in Obłazowa Cave (western entrance), came from the post-warming period. The compared assemblages were very rich taxonomically, comprising altogether over 18,700 determined fossil items, representing over 7500 specimens and about 138 taxa, which allowed for reliable palaeoenvironmental analyses. We reconstructed faunal succession that evidenced a gradual environmental change occurring as early as between ca. 17.0 and 14.0 $\mathrm{ka}$. Our data suggest that the major abrupt warming around GS-2/GI-1 boundary had little impact on the environment in the Polish Western Carpathians. The increase in species diversity in local biotopes was gradual and began before the general increase in temperatures in the Northern Hemisphere. Interestingly, the changes in the faunal assemblages and bioclimatic parameters were even greater in the period before the global GS-2a/GI-1e warming. This view is also supported by a gradual increase in the effective population size of the common vole (Microtus arvalis), starting in $19.0 \mathrm{ka}$ and confirming that biotopes suitable for this species developed earlier. The vertebrate fauna found in the Rock overhang in Cisowa Rock indicated that differentiated biotopes already existed in GS-2a. The results of the palaeoclimatic reconstruction showed that the compared sites had similar climatic conditions. The differences in the mean annual temperatures did not exceed $0.5^{\circ} \mathrm{C}$, and the mean annual amplitude fell from 22.9 to $22.4^{\circ} \mathrm{C}$. The gradual environmental change also manifested in a decrease in species preferring open tundra landscapes and an increase in dwellers of patchy and more diversified biotopes. The presence of differentiated environments in the Western Carpathians at the end of GS-2a and during GI1e correlates well with the development of Final Palaeolithic settlements; however, it is important to note that there is a lack of evidence for human presence in the area just after the LGM (between ca. 18.0 and ca. $16.0 \mathrm{ka}$ ) despite the presence of suitable environmental conditions for settlement. The first Late Magdalenian groups appeared in the Orawa-Nowy Targ Basin just before the major warming ca. $14.7 \mathrm{ka}$, as documented in OB(WE) layer III. However, only in the Bølling (GI-1e) was Magdalenian settlement confirmed, by findings in the main chamber of Obłazowa Cave. At the beginning of the Allerød (GI- $\left.1 \mathrm{c}_{3}\right)$, settlements of Late Magdalenian groups were still present at $\mathrm{OB}(\mathrm{WE})$ and other sites. The inhabitation of the region continued, as Federmesser groups appeared in the second half of this interstadial $\left(\mathrm{GI}^{-}-\mathrm{c}_{1 \mathrm{~b}}\right)$ in the Nowa Biała 1 open-air campsite. It is remarkable that in the Polish Western Carpathians traces of the Epigravettian have not been found.

The main, rather unexpected result of this study is that the global warming at ca.14.7 ka had a little influence on environmental changes in the intra-mountain basin and that the diversity and mosaicism of the local environment was already relatively high before the abrupt warming, during the post-LGM deglaciation period. These findings may imply that local ecosystems were resilient to the global climate shift. We found bigger changes in the fauna and environments prior to the 14.7 ka global warming, which suggests that changes in 
$\delta^{18} \mathrm{O}$ of Greenland ice cores were delayed compared with the transitions in climate, fauna and environment in Central Europe. However, the absence of traces of human activity in this area before ca. 16.0 ka suggests that the variety of biotopes available for humans were apparently not sufficiently attractive for settlement or the groups had not yet had the opportunity to come across this region.

Acknowledgements The study received funding from the National Science Centre, Poland, grant numbers UMO-2017/25/B/NZ8/02005 (to A.N.), 2015/19/D/NZ8/03878 (to M.B.), UMO-2015/17/B/HS3/ 00181(to P.V.-N.) and UMO-2016/20/S/ST10/00163 (to A.P-S). We wish to thank T. Goslar of the Poznań Radiocarbon Laboratory (Poz) and Beta Analytic, Miami (Beta) for ${ }^{14} \mathrm{C}$ AMS dating. Species determination expertise was provided by Z.S. (Amphibia and Reptilia), T.T. and K.W. (Aves), A.P-S. (Eulipotyphla and Chiroptera), A.L., A.N., B.M. (Lagomorpha and Rodentia), G.L. (Carnivora and Ungulata); M.B., D.P. and A.Ż performed the laboratory work on aDNA; M.B. performed the phylogenetic analysis; A.L. and P.S. performed the palaeoenvironmental reconstruction; P.S performed the palaeoclimatic reconstruction; P.V.-N., A.K. and M.C. provided archaeological expertize; P.M. conducted and described the analyses of faunal changes; A.N. and M.B designed the study; A.N., M.B., P.M., A.L., K.W., P.S., and P.V.$\mathrm{N}$ wrote the manuscript with input from all authors.

\section{Compliance with ethical standards}

Conflict of interest The authors declare that they have no conflict of interest.

Open Access This article is licensed under a Creative Commons Attribution 4.0 International License, which permits use, sharing, adaptation, distribution and reproduction in any medium or format, as long as you give appropriate credit to the original author(s) and the source, provide a link to the Creative Commons licence, and indicate if changes were made. The images or other third party material in this article are included in the article's Creative Commons licence, unless indicated otherwise in a credit line to the material. If material is not included in the article's Creative Commons licence and your intended use is not permitted by statutory regulation or exceeds the permitted use, you will need to obtain permission directly from the copyright holder. To view a copy of this licence, visit http://creativecommons.org/licenses/by/4.0/.

\section{References}

Alexandrowicz SW, Drobniewicz B, Ginter B, Kozłowski JK, Madeyska T, Nadachowski A, Pawlikowski M, Sobczyk K, Szyndlar Z, Wolsan M (1992) Excavations in the Zawalona Cave at Mników (Cracow Upland, southern Poland). Folia Quaternaria 63:43-76

Allen JRM, Brandt U, Brauer A, Hubberten HW, Huntley B, Keller J, Kraml M, Mackensen A, Mingram J, Negendank JFW, Nowaczyk NR, Oberhansli H, Watts WA, Wulf S, Zolitschka B (1999) Rapid environmental changes in southern Europe during the last glacial period. Nature 400:740-743

Andrews P (1990) Owls, caves and fossils. Predation, preservation and accumulation of small mammal bones in caves, with an analysis of the Pleistocene cave faunas from Westbury-sub-Mendip, Somerset, UK. British Museum (natural history), London

Andrews P (2006) Taphonomic effects of faunal impoverishment and faunal mixing. Palaeogeogr Palaeoclimatol Palaeoecol 241:572-589
Baca M, Popović D, Lemanik A, Baca K, Horáček I, Nadachowski A (2019) Highly divergent lineage of narrow-headed vole from the Late Pleistocene Europe. Sci Rep 9:17799

Baumgart-Kotarba M (1996) The origin and age of the Orawa Basin, West Carpathians. Studia Geomorphologica Carpatho-Balcanica 30:101-116

Berto C, Boscato P, Boschin F, Luzi E (2017) Paleoenvironmental and paleoclimatic context during the Upper Palaeolithic (late Upper Pleistocene) in the Italian Peninsula. The small mammal record from Grotta Paglicci (Rignano Garganico, Foggia, Southern Italy). Quat Sci Rev 168:30-41

Blockley SPE, Lane CS, Hardiman M, Rasmussen SO, Seierstad IK, Steffensen JP, Svensson A, Lotter AF, Turney CSM, Ramsey CB (2012) Synchronisation of palaeoenvironmental records over the last 60,000 years, and an extended INTIMATE event stratigraphy to 48, 000 b2k. Quat Sci Rev 36:2-10

Bocheński Z, Tomek T (2004) Bird remains from a rock-shelter in Krucza Skała (Central Poland). Acta Zool Cracov 47(1-2):27-47

Bronk Ramsey C, Higham T, Bowles A, Hedges REM (2004) Improvements to the pretreatment of bone at Oxford. Radiocarbon 46(1):155-163

Bronk Ramsey C (2017) OxCal 4.3.2 Manual. https://c14.arch.ox.ac.uk/ oxcal/OxCal.html

Charles CD, Rind D, Jouzel J, Koster RD, Fairbanks RG (1994) Glacialinterglacial changes in moisture sources for Greenland: influences on the ice core record of climate. Science 263:508-511

Clark PU, Shakun JD, Baker PA, Bartlein PJ, Brewer S, Brook E, Carlson AE, Cheng H, Kaufman DS, Liu Z, Marchitto TM, Mix AC, Morrill C, Otto-Bliesner BL, Pahnke K, Russell JM, Whitlock C, Adkins JF, Blois JL, Clark J, Colman SM, Curry WB, Flower BP, He F, Johnson TC, Lynch-Stieglitz J, Markgraf V, McManus J, Mitrovica JX, Moreno PI, Williams JW (2012) Global climate evolution during the last deglaciation. Proceedings of the National Academy of Sciences of the United States of America 109,19:E1134-E1142

Dabney J, Knapp M, Glocke I, Gansauge M-T, Weihmann A, Nickel B, Valdiosera C, García N, Pääbo S, Arsuaga J-L, Meyer M (2013) Complete mitochondrial genome sequence of a middle Pleistocene cave bear reconstructed from ultrashort DNA fragments. Proc Natl Acad Sci U S A 110:15758-15763

Drobniewicz B, Doktor M, Sobczyk K (1997) Petrographical composition and provenance of siliceous artefacts on the archeological sites in the regions of Spisz and the Pieniny mountains (southern Poland). In: Schild R, Sulgustowska Z (eds) Man and Flint. Institute of Archaeology and Ethnology. Polish of Sciences, Warszawa, pp 195-200

Drummond AJ, Suchard MA, Xie D, Rambaut A (2012) Bayesian phylogenetics with BEAUti and the BEAST 1.7. Mol Biol Evol 29: 1969-1973

Dryja S, Rydlewski J (1991) Nowe stanowiska z epoki kamienia w Kotlinie Orawsko-Nowotarskiej. Acta Archaeologica Carpathica 30:213-222 [in Polish]

Evans EMN, Van Couvering JAH, Andrews P (1981) Palaeoecology of Miocene sites in Western Kenya. J Hum Evol 10:99-116

Fernández-Jalvo Y, Andrews P, Denys C, Sesé C, Stoetzel E, Martín-Monfort D, Pesquero D (2016) Taphonomy for taxonomists: implications of predation in small mammal studies. Quat Sci Rev 139:138-157

Feurdean A, Perşoiu A, Tanțău I, Stevens T, Magyari EK, Onac BP, Marković S, Andrič M, Connor S, Fărcaș S, Gałka M, Gaudeny T, Hoek W, Kolaczek P, Kuneš P, Lamentowicz M, Marinova E, Michczyńska DJ, Perşoiu I, Płóciennik M, Słowiński M, Stancikaite M, Sumegi P, Svensson A, Tămaș T, Timar A, Tonkov S, Toth M, Veski S, Willis KJ, Zernitskaya V (2014) Climate variability and associated vegetation response throughout central and Eastern Europe (CEE) between 60 and 8 ka. Quat Sci Rev 106:206-224

Fletcher WJ, Sánchez Goñi MF, Allen JRM, Cheddadi R, CombourieuNebout N, Huntley B, Lawson I, Londeix L, Magri D, Margari V, Müller UC, Naughton F, Novenko E, Roucoux K, Tzedakis PC 
(2010) Millennial-scale variability during the last glacial in vegetation records from Europe. Quat Sci Rev 29(21-22):2839-2864

Gleń-Haduch E (2003) Human remains. In: Valde-Nowak P, Nadachowski A, Madeyska T (eds) Obłazowa Cave: human activity, stratigraphy and palaeoenvironment. Institute of Archaeology and Ethnology Polish Academy of Sciences, pp 89-90

Goslar TF, Czernik J, Goslar E (2004) Low-energy 14C AMS in the Poznan radiocarbon laboratory, Poland. Nucl Instr and Meth B223-224:5-11

Hernández Fernández M (2001a) A bioclimatic discriminant capacity of terrestrial mammal faunas. Glob Ecol Biogeogr 10:189-204

Hernández Fernández M (2001b) Análisis paleoecológico y paleoclimático de las sucesiones de mamiferos del Plio-Pleistoceno ibérico. Universidad Complutense de Madrid, Madrid [in Spanish]

Hernández Fernández M (2006) Rodent paleofaunas as indicators of climatic change in Europe during the last 125,000 years. Quat Res 65: 308-323

Hernández Fernández M, Peláez-Campomanes P (2003) The bioclimatic model: a method of palaeoclimatic qualitative inference based on mammal associations. Glob Ecol Biogeogr 12:507-517

Hernández Fernández M, Peláez-Campomanes P (2005) Quantitative palaeoclimatic inference based on terrestrial mammal faunas. Glob Ecol Biogeogr 14:39-56

Holling CS (1973) Resilience and stability of ecological systems. Annu Rev Ecol Syst 4:1-23

Horn S (2012) Target enrichment via DNA hybridization capture. Methods and protocols. Springer, Ancient DNA, pp 177-188

Hromada J, Kozłowski JK (1995) Complex of Upper Palaeolithic sites near Moravany, Western Slovakia, Moravany-Žakovska (excavations 1991-1992). Kraków

Huber C, Leuenberger M, Spahni R, Flückiger J, Schwander J, Stocker TF, Johnsen S, Landais A, Jouzel J (2006) Isotope calibrated Greenland temperature record over marine isotope stage 3 and its relation to $\mathrm{CH}_{4}$. Earth Planet Sci Lett 243:504-519

IUCN 2019. The IUCN red list of threatened species. Version 2019-1. http://www.iucnredlist.org. Downloaded on 21 March 2019

Jackson ST, Blois J (2015) Community ecology in a changing environment: perspectives from the Quaternary. Proc Natl Acad Sci U S A 112:4915-4921

Jamrichová E, Petr L, Jiménez-Alfaro B, Jankovská V, Dudová L, Pokorný P, Kołaczek P, Zernitskaya V, Čierniková M, Bř́zová E, Syrovátka V, Hájková P, Hájek M (2017) Pollen-inferred millennial changes in landscape patterns at a major biogeographical interface within Europe. J Biogeogr 44(10):2386-2397

Jura A (1955) Grota Magury w Tatrach (1460 m), najwyżej w Polsce położona siedziba człowieka epoki lodowej. Światowid 21:81-24 [in Polish]

Kazior B, Kozłowski JK, Sobczyk K (1998) Lithic inventories. In: Kozłowski JK (ed) complex of Upper Palaeolithic sites near Moravany, Western Slovakia, Moravany-Lopata II (excavations 1993-1996), vol 2. Elsevier, Kraków, pp 43-83

Kowalski K (ed) (1989) Historia i ewolucja lądowej fauny Polski. Folia Quaternaria 59-60:1-278 [in Polish]

Kozłowski JK, Sobczyk K (1987) The Upper Paleolithic site KrakówSpadzista street C2. Excavations 1980. Prace Archeologiczne 42:7-68

Kozłowski SK, Połtowicz-Bobak M, Bobak D, Terberger T (2012) New information from Maszycka Cave and the Late Glacial recolonisation of Central Europe. Quat Int 272-273:288-296

Kryštufek B, Tesakov AS, Lebedev VS, Bannikova AA, Abramson NI, Shenbrot G (2019) Back to the future: the proper name for redbacked voles is Clethrionomys Tilesius and not Myodes Pallas. Mammalia, https://doi.org/10.1515/mammalia-2019-0067

Langen PL, Vinther BM (2009) Response in atmospheric circulation and sources of Greenland precipitation to glacial boundary conditions. Clim Dyn 32:1035-1054

Lengyel G (2016) Reassessing the Middle and Late Upper Palaeolithic in Hungary. Acta Archaeologica Carpathica 51:47-66
Li H, Handsaker B, Wysoker A, Fennell T, Ruan J, Homer N, Marth G, Abecasis G, Durbin R, Subgroup, 1000 Genome Project Data Processing (2009) The sequence alignment/map format and SAMtools. Bioinformatics 25:2078-2079

Lindgreen S (2012) AdapterRemoval: easy cleaning of next-generation sequencing reads. BMC Res Notes 5:337

Lorenc M (2006) Radiocarbon dating of some Late Pleistocene assemblages in caves in Poland. Acta Zool Cracov 49(1-2):41-61

López-García JM, Blain H-A, Cuenca-Bescós G, Ruiz-Zapata MB, Dorado- Valiñno M, Gil-García MJ, Valdeolmillos A, Ortega AI, Carretero JM, Arsuaga JL, de Castro JMB, Carbonell E (2010) Palaeoenvironmental and palaeoclimatic reconstruction of the latest Pleistocene of El Portalón site, Sierra de Atapuerca, northwestern Spain. Palaeogeogr Palaeoclimatol Palaeoecol 292:453-464

Łanczont M, Madeyska T, Hołub B, Komar M, Mroczek P, Standzikowski K, Valde-Nowak P, Kraszewska A, Cieśla M, Skłucki J (2019) Late glacial environment and human settlement of the Central Western Carpathians: a case study of the Nowa Biała 1 open-air site (Podhale region, southern Poland). Quat Int 512:113-132. https://doi.org/10.1016/j.quaint.2019.02.036

Madeyska T, Cyrek K (2002) Cave fillings - a chronicle of the past. An outline of the younger Pleistocene cave sediments study in Poland. Acta Geol Pol 52(1):75-95

Maguire KC, Nieto-Lugilde D, Fitzpatrick MC, Williams JW, Blois JL (2015) Modeling species and community responses to past, present, and future episodes of climatic and ecological change. Annu Rev Ecol Evol Syst 46:343-368

Meyer M, Kircher M (2010) Illumina sequencing library preparation for highly multiplexed target capture and sequencing. Cold Spring Harb Protoc 5:1-10

Moreno A, Svensson A, Brooks SJ, Connor S, Engels S, Fletcher W, Genty D, Heiri O, Labuhn I, Perşoiu A, Peyron O, Sadori L, Valero-Garcés B, Wulf S, Zanchetta G (2014) A compilation of Western European terrestrial records 60-8 ka BP: towards an understanding of latitudinal climatic gradients. Quat Sci Rev 106:167-185

Mourier T, Ho SYW, Gilbert MTP, Willerslev E, Orlando L (2012) Statistical guidelines for detecting past population shifts using ancient DNA. Mol Biol Evol 29(9):2241-2251

Nadachowski A, Bratlund B, Tomek T, Miękina B, Stworzewicz E, Szyndlar Z (2014) Faunal remains from Wilczyce and the paleoecological reconstruction of the area at the end of the Pleniglacial. In: Schild R (ed) A late Magdalenian winter hunting camp in southern Poland. Institute of Archaeology and Ethnology Polish Academy of Sciences, Warszawa, pp 119-134

Nadachowski A, Miękina B, Garapich A (2003) Rodents (Rodentia). In: Valde-Nowak P, Nadachowski A, Madeyska T (eds) Obłazowa cave human activity stratigraphy and palaeoenvironment. Institute of Archaeology and Ethnology Polish Academy of Sciences, Kraków, pp 134-140

Nadachowski A, Valde-Nowak P (2015) New Late Pleistocene faunal assemblages from Podhale Basin, Western Carpathians, Poland: preliminary results. Acta Zool Cracov 58:181-194

Nadachowski A, Żarski M, Urbanowski M, Wojtal P, Miękina B, Lipecki G, Ochman K, Krawczyk M, Jakubowski G, Tomek T (2009) Late Pleistocene environment of the Częstochowa upland (Poland) reconstructed on the basis of faunistic evidence from archaeological cave sites. Institute of Systematics and Evolution of Animals. Polish Academy of Sciences, Kraków

Rambaut A, Drummond AJ, Xie D, Baele G, Suchard MA (2018) Posterior summarization in Bayesian Phylogenetics using tracer 1.7. Syst Biol 67:901-904

Rasmussen SO, Bigler M, Blockley SP, Blunier T, Buchardt SL, Clausen HB, Cvijanovic I, Dahl-Jensen D, Johnsen SJ, Fischer H, Gkinid V, Guillevic M, Hoek WZ, Lowe JJ, Pedro JB, Popp T, Seierstad IK, Steffensen JP, Svensson AM, Vallelonga P, Vinther BM, Walker MJC, Wheatley JJ, Winstrup M (2014) A stratigraphic framework 
for abrupt climatic changes during the last glacial period based on three synchronized Greenland ice-core records: refining and extending the INTIMATE event stratigraphy. Quat Sci Rev 106:14-28

Reimer PJ, Bard E, Bayliss A, Beck JW, Blackwell PG, Bronk Ramsey C, Buck CE, Cheng H, Edwards RL, Friedrich M, Grootes PM, Guilderson TP, Haflidason H, Hajdas I, Hatté C, Heaton TJ, Hoffmann DL, Hogg AG, Hughen KA, Kaiser KF, Kromer B, Manning SW, Niu M, Reimer RW, Richards DA, Scott EM, Southon JR, Staff RA, Turney CSM, Van der Plicht J (2013) IntCal13 and Marine13 radiocarbon age calibration curves, 0-50, 000 years cal BP. Radiocarbon 55(4):1869-1887

Renssen H, Isarin RFB (2001) The two major warming phases of the last deglaciation at $\sim 14.7$ and $\sim 11.5 \mathrm{ka}$ cal BP in Europe: climate reconstructions and AGCM experiments. Glob Planet Chang 30:117-153

Rivas-Martinez S, Rivas-Sáenz S (1996-2009) Worldwide Bioclimatic Classification System. www.globalbioclimatics.org

Royer A, Montuire S, Gilg O, Laroulandie V (2019) A taphonomic investigation of small vertebrate accumulations produced by the snowy owl (Bubo scandiacus) and its implications for fossil studies. Palaeogeogr Palaeoclimatol Palaeoecol 514:189-205

Royer A, Montuire S, Legendre S, Discamps E, Jeannet M, Lécuyer C (2016) Investigating the influence of climate changes on rodent communities at a regional-scale (MIS 1-3, southwestern France). PLoS One 11(1):e0145600

Rydlewski J (1990) Z badań nad kulturą świderską w północnych Karpatach. Acta Archaeologica Carpathica 29:5-31 [in Polish]

Rzebik-Kowalska B (2003) Insectivores (Insectivora) in: Valde-Nowak P, Nadachowski A, Madeyska T (ed) Obłazowa cave human activity stratigraphy and palaeoenvironment. Institute of Archaeology and Ethnology Polish Academy of Sciences, Kraków, pp 113-118

Shakun JD, Clark PU, He F, Marcott SA, Mix AC, Liu Z, Otto-Bliesner B, Schmittner A, Bard E (2012) Global warming preceded by increasing carbon dioxide concentrations during the last deglaciation. Nature 484:49-54

Socha P (2014) Rodent palaeofaunas from Biśnik cave (KrakówCzęstochowa Upland, Poland): palaeoecological, palaeoclimatic and biostratigraphic reconstruction. Quat Int 326-327:64-81

Sommer RS, Nadachowski A (2006) Glacial refugia of mammals in Europe: evidence from fossil records. Mammal Rev 36(4):252-265

Stefaniak K, Nadachowski A, Tomek T, Socha P (2009) Palaeontological studies in the Częstochowa Upland. In: Stefaniak K, Tyc A, Socha P (eds) Karst of the Czestochowa Upland and of the Eastern Sudetes: palaeoenvironments and protection. Studies of the Faculty of Earth Sciences, University of Silesia, Sosnowiec-Wrocław, pp 85-144

Steffensen JP, Andersen KK, Bigler M, Clausen HB, Dahl-Jensen D, Fischer H, Goto-Azuma K, Hansson M, Johnsen SJ, Jouzel J, Masson-Delmotte V, Popp T, Rasmussen SO, Röthlisberger R, Ruth U, Stauffer B, Siggaard-Andersen M-L, Sveinbjörnsdóttir ÁE, Svensson A, White JWC (2008) High resolution Greenland ice core data show abrupt climate change happens in few years. Science 321:680-684

Tokarski AK, Świerczewska A, Zuchiewicz W, Starek D, Fodor L (2012) Quaternary exhumation of the Carpathians: a record from OravaNowy Targ Intramontane Basin, Western Carpathians (Poland and Slovakia). Geol Carpath 64(4):257-266

Tomek T, Bocheński Z, Bocheński ZM (2003) Birds (Aves) in: Valde-Nowak P, Nadachowski a, Madeyska T (ed) Obłazawa cave: human activity, stratigraphy and palaeoenvironment. Institute of Archaeology and Ethnology Polish Academy of Sciences, Kraków, pp 102-113

Triant DA, DeWoody JA (2008) Molecular analyses of mitochondrial pseudogenes within the nuclear genome of arvicoline rodents. Genetica 132:21-33

Trinkaus E, Haduch E, Valde-Nowak P, Wojtal P (2014) The Obłazowa 1 pollical distal phalanx and Late Pleistocene distal thumb proportions. HOMO - J Comparat Human Biol 65(1):1-12
Valde-Nowak P (1987) Entdeckung der paläolithischen Fundstellen im Tal des Białka Tatrzańska-Flusses. Acta Archaeologica Carpathica XXVI:5-35

Valde-Nowak P (1991) Studies in Pleistocene settlement in the Polish Carpathians. Antiquity 65:593-606

Valde-Nowak P (2015) Paleolit Karpat Polskich i ich przedpola. In: Łanczont M, Madeyska T (eds) Paleolityczna ekumena strefy pery- i metakarpackiej. University of Maria Curie-Skłodowska, Lublin, pp 643-690 [in Polish]

Valde-Nowak P, Alex B, Ginter B, Krajcarz MT, Madeyska T, Miękina B, Sobczyk K, Stefański D, Wojtal P, Zając M, Zarzecka-Szubińska K (2016) Late Middle Palaeolithic occupations in Ciemna cave, southern Poland. J Field Archaeol 41(2):193-210

Valde-Nowak P, Łanczont M, Pawłowska M (2006) The Upper Palaeolithic site at Ujazd (Polish Carpathians). Acta Archaeologica Carpathica 40:5-26

Valde-Nowak P, Kraszewska A, Cieśla M (2017) Magdalenian figurine from Obłazowa Cave. Acta Archaeologica Carpathica 52:299-304

Valde-Nowak P, Kraszewska A, Cieśla M, Nadachowski A (2018) Late Magdalenian campsite in a rock shelter at the Obłazowa Rock. In: Valde-Nowak P, Sobczyk K, Nowak M, Żrałka J (eds) Multas per Gentes et Multa per Saecula. Anici magistro et college suo ioanni Christopho Kozłowski dedicant. Institute of Archeology, Jagiellonian University, Kraków, pp 175-183

Valde-Nowak P, Muzyczuk A (1999) Magdalenian settlement at Hłomcza (polish Carpathians). Acta Archaeologica Carpathica 35:5-32

Valde-Nowak P, Nadachowski A (2014) Micoquian assemblage and environmental conditions for the Neanderthals in Obłazowa Cave, Western Carpathians, Poland. Quat Int 326-327:146-156

Valde-Nowak P, Nadachowski A, Madeyska T (2003) Obłazowa Cave: human activity, stratigraphy and palaeoenvironment. Institute of Archaeology and Ethnology Polish Academy of Sciences, Kraków

Valde-Nowak P, Nadachowski A, Wolsan M (1987) Upper Palaeolithic boomerang made of a mammoth tusk in South Poland. Nature 329:436-438

Valde-Nowak P, Soják M, Wąs M (2007) On the problems of Late Paleolithic settlement in northern Slovakia. Example of Stará Lubovňa site, Slovenská archeológia 55(1):1-22

Walter H (1970) Vegetationszonen und Klima. Eugen Ulmer, Stuttgart

Werner M, Heimann M, Hoffmann G (2001) Isotopic composition and origin of polar precipitation in present and glacial climate simulations. Tellus Ser B Chem Phys Meteorol 53:53-71

Werner M, Mikolajewicz U, Heimann M, Hoffmann G (2000) Borehole versus isotope temperatures on Greenland: seasonality does matter. Geophys Res Lett 27:723-726

Wilczyński J (2014) Zabytki kamienne odkryte w kontekście obiektów kultury łużyckiej z osady otwartej oraz cmentarzyska odkrytego na stanowisku Targowisko 10, 11 gm. Kłaj, pow. wielicki, In: Górski J (ed) Kompleks osadniczy kultury łużyckiej w Targowisku, stan. 1012, pow. Wielicki, „Via Archaeologica. Źródła z badań wykopaliskowych na trasie autostrady A4 w Małopolsce", Kraków, pp. 231-241 [in Polish]

Wiśniewski A, Połtowicz-Bobak M, Bobak D, Jary Z, Moska P (2017) The Epigravettian and the Magdalenian in Poland: new chronological data and an old problem. Geochronometria 44:16-29

Wolff EW, Chappellaz J, Blunier T, Rasmussen SO, Svensson A (2010) Millennial-scale variability during the last glacial: the ice core record. Quat Sci Rev 29:2828-2838

Wong GL, Drucker DG, Starkovich BM, Conard NJ (2020) Latest Pleistocene paleoenvironmental reconstructions from the Swabian Jura, southwestern Germany: evidence from stable isotope analysis and micromammal remains. Palaeogeogr Palaeoclimatol Palaeoecol $540: 109527$

Publisher's note Springer Nature remains neutral with regard to jurisdictional claims in published maps and institutional affiliations. 